Article

\title{
Typology and the Holocaust: Erich Auerbach and Judeo-Christian Europe
}

\author{
Malachi Haim Hacohen \\ History Department, Duke University, Box 90719, Durham, NC 27708, USA; \\ E-Mail:mhacohen@duke.edu
}

Received: 25 May 2012; in revised form: 7 July 2012 / Accepted: 11 July 2012 /

Published: 17 July 2012

\begin{abstract}
In response to Nazi exclusion of the Jews from German society on racial grounds, Erich Auerbach (1892-1957), a secular Jewish intellectual inspired by cultural Protestantism and Catholicism, formed a vision of a cosmopolitan Judeo-Christian civilization that reintegrated the Jews as biblical founders and cultural mediators. But the integration expunged any mark of traditional Jewishness. Focusing on Christian figurative thinking (typology), Auerbach viewed the binding of Isaac through the crucifixion, and contemporary Jews as civilization's (unwilling and undeserving) martyrs. In the aftermath of the Holocaust, his cosmopolitanism reached a crisis, reflected in his postwar vision of Western decline. The progressive mandarin who had begun his intellectual life elevating Dante's care for everyday life and sympathizing with French realist social critique ended endorsing Hugh of St. Victor's alienation from reality and Pascal's acquiescence in totalitarian rule.
\end{abstract}

Keywords: Auerbach; émigrés; cosmopolitanism; Judeo-Christian; typology; Holocaust; figura; Akedah; Mimesis; everydayness

\section{Introduction}

Among the Jewish émigrés who sought sanctuary in World War II on the outskirts of the old continent, in Istanbul University, was literary historian and philologist Erich Auerbach (1892-1957), author of the monumental Mimesis: The Representation of Reality in Western Literature (1946) [1,2]. In 1947 he immigrated to the U.S. and sent Mimesis to an admired German author, Thomas Mann, who was commuting between his U.S. war refuge in Palisades Heights and his postwar European one in 
Ascona, Switzerland. Mimesis' "central theme, European realism, has the greatest attraction for me," responded Mann in 1949. "Your approach, treating [realism] historically and tracking the everlasting artistic disposition for it through the centuries carries a pedagogical message" [3]. Neither of them spoke openly about the Holocaust. Ironically, Mann resurrected biblical myth to respond to Nazi racial one, whereas Auerbach saw Mann's realism, and biblical insistence on truth as opposed to classical myth, as the only proper response. But both questioned the German humanist focus on the classical and the claim to ownership over it, and both resurrected the Hebrew Bible to challenge the hegemony of the classical heritage in German culture. In ways often underappreciated, secular German and Jewish intellectuals responded to National Socialism by reaffirming a Judeo-Christian Western tradition $[4,5]$.

\section{Vico and Dante: A Jewish Cultural Protestant in Weimar Germany}

Born to an affluent and German acculturated Berlin Jewish family, Auerbach grew up in a predominantly Jewish neighborhood in Charlottenburg, and attended the French gymnasium (französisches Gymnasium), first established by Huguenot exiles and now carrying on French cultural traditions. Auerbach was by no means an accomplished student, but republican France became his second Heimat and his future pursuit of romance languages owed much to this early French exposure. Son of a jurist, he pursued law, earning a doctoral degree from Heidelberg in 1913. In Heidelberg, he apparently made the acquaintance of several members of the Max Weber circle, including Georg Lukàcs, Walter Benjamin, and Karl Jaspers [6,7]. French sympathies made no dent in his German patriotism: He served on the western front in WWI, was wounded and decorated. The loss of friends was traumatic but, like the Holocaust later, he consigned it to silence. Auerbach's literary concerns alone alluded to the pain, loss and injustice of a cruel and unpredictable world.

Returning to civil life, Auerbach sought a change of profession. In 1921, he earned a second doctorate in Romance philology with a dissertation on French and Italian early Renaissance novellas. The rise of the novella, he suggested, reflected the historical transition from the medieval to the Renaissance world, the rise of Renaissance man, conscious of his individuality, seeing himself in the midst of earthly life (irdischen Dasein) [8]. His early publications, dedicated to Dante, launched into arguments he would pursue throughout life. Dante's characters in The Divine Comedy, though they inhabited Hell, Purgatory and Paradise, forever retained their earthly nature. Auerbach celebrated Dante as a German poet, an Italian who joined, as Shakespeare did, a German-European pantheon [9-11]. Dante spoke to Germany's spiritual crisis because he conveyed confidence in the viability of a Christian community and a providentially guided universe, where rewards and punishments were justly meted, and the protagonists' character was their destiny. This confidence, Auerbach recognized, was now woefully lost. He was groping for a literary sensibility appropriate to a secularized Christian culture, for a dignified attention to the social world, to everydayness (täglichen Dasein).

"A Prussian of the Mosaic faith," Auerbach described himself in the dissertation's bio [12]. In 1923, he married Marie Mankiewitz, daughter to an affluent Jewish family (the largest private shareholder of Deutsche Bank) [13]. He gave his son, born later that year, the distinctly Christian name Clemens, and did not have him circumcised (until a doctor recommended the procedure for medical reasons fourteen years later) [14]. There was nothing traditionally Jewish in Auerbach's education or 
culture. He accepted the liberal Protestant view, articulated by theologian and historian Adolf von Harnack, that postbiblical Judaism no longer retained its intellectual vitality and became obsolete, a particularist religion in a universal Christian world. Yet the liberal Protestant call to Jews to convert and become part of the German nation never seemed to tempt him, and he remained a member of the Jewish community. Unlike Franz Werfel, he did not think of the Jews, in an Augustinian fashion, as witnesses to Christian truth. A cultural Christian of Jewish origins, he could not believe in Jesus as Christ, and accepted his Jewish fate with composure [15].

Cultural Protestantism shaped Auerbach's view of contemporary life. He thought that secularization and historicism created a cultural crisis that left the world disenchanted, devoid of firm cultural norms. A student of philosopher and theologian Ernst Troeltsch (1865-1923) - he attended Troeltsch's seminar and belonged to his circle in the Weimar Republic's early years-Auerbach searched for the secular equivalent of Christian religious ideals $[16,17]$. Harnack and Weber, too, inspired his historical mode of inquiry but all three, Harnack, Troeltsch and Weber, left him without answers. Like them, he was willing to see modern cultural values as vouched in the nation, but they lacked his social sensitivity. He viewed the Christian concern for the poor as exemplary of attentiveness to daily life, and upheld St. Francis as the embodiment of authenticity [18]. His fascination with the sacred and his affinity for the downtrodden were reminiscent of Expressionist artists and writers. Weber made light of such sensibilities, but they became the overriding theme of Auerbach's lifelong work [19].

Troeltsch represented liberal historical theology pushed to its limits. His history denuded Christianity of supernaturalist claims, the Incarnation included. Jesus became a world historical figure, embodying humanity's aspirations, founder of a Christian culture that evolved into Europe's legacy. Troeltsch's comparative study of world religions progressively disrupted his sense of Christian and European superiority. The cultural relativism historicism occasioned was palpable and painful to him, a Protestant theologian, and he looked back longingly to medieval Europe as an integral civilization free of doubt. Yet, even in the aftermath of WWI, Troeltsch was still hoping, against hope, that history would reveal a transcendental pattern [20,21].

Troeltsch's Jesus, a world historical figure, became a point of departure for Auerbach's life-long work. Like Troeltsch, Auerbach secretly believed that history displayed divine intentions and searched his entire life for patterns rendering its meaning. Like him, he longed for past communities where God and man cohabited peacefully. National Socialism constituted a caesura because it became impossible for Auerbach to reconcile "all the evil that is happening" with "God and the eternal world" [22]. He never ceased searching for meaning in history but, in the post-Holocaust years, hope would be gone.

Much as Troeltsch and Auerbach craved meaningful patterns, they rebuffed the Hegelian confidence in a universal history, and refused a unifying narrative integrating the plurality of cultures. In Oswald Spengler's The Decline of the West, Troeltsch saw a monistic history, hostile to liberal culture [23]. Seeking counter models, Troeltsch encouraged Auerbach to study the Italian philosopher of history, Giambattista Vico (1668-1744), who was not well known in Germany at the time. To Vico, culture was a human creation, and history a succession of epochs, represented in a plurality of nations, each an aspect of the divine. His "world of nations" consisted of civil societies at divergent stages of development spread around the globe, following a pattern, leading from aristocratic polities, imagining gods and heroes governing, to rational organization in monarchies and republics. Troeltsch and Auerbach found in Vico a history accentuating cultural pluralism, divinely inspired but human made. 
Vico became the site for the interplay of tensions between universalism and pluralism, divine and human, which Auerbach never wished to resolve or think to their end, allowing them to coexist and motivate his work.

As Auerbach became, in 1923, a librarian at the Prussian National Library, he had the leisure to translate Vico's Scienza Nuova and engage his views on language, culture and history [24,25]. "Vico's conception of philology and of the "world of nations'," he said in the postwar years (when he thought the world of nations was approaching its end), "complemented and molded, in my thinking and in my work, the ideas deriving from German historicism" [26]. Auerbach's distaste for Cartesian rationalism and French classicism, his consciousness of the multiple perspectives available into a historical period, his historical philology and contextual approach to literature, and his interpretive reenactment of historical agents, all reflected an adaptation of German historicism via Vico. He rejected only Vico's cyclical historical determinism, which was too reminiscent of Spengler. In "Vico und Herder" (1932), he suggested that Vico parted with Christian transcendentalism by having providence work its way immanently through history, a move toward secularization [27]. Yet, Vico did not question the individual's relationship to God, and, like Vico, Auerbach was content to live with the tension between an immanent history and a transcendently oriented individual. He declined to move toward an emphatically secular historicism.

Vico made it easier for Auerbach to escape, if only barely, the traps of Heidegger and the "Conservative Revolution." Auerbach admired Stefan George-his Dante book was, at points, reminiscent of the hero-worshipping biographies of the George Circle — and he thought Heidegger a profound thinker. "An awful fellow," he said after WWII, "I am glad I did not fall into his hands when I was young." "But," he added, "he had substance" [28,29]. In the Weimar years, young academic Germany turned against formal and idealist philosophy in search of authenticity. The poet embodied authenticity, whether in the aristocratic heroic fashion of the George Circle or in Heideggerian overcoming of the "everydayness of existence" (Alltäglichkeit des Daseins). One sought to explore the "life-world" as it revealed itself, uncorrupted by the traditional philosophical pursuit of objectivity [30,31]. "Everydayness" became a central motif for Auerbach but with a "progressive" twist, one affirming the grandeur of the daily struggles of the downtrodden [32]. He made literary concern for the everyday tragic the acid test of modern literature, and he judged the success of literary realism by its grasp of concrete social life. He found the seventeenth-century French classical tragedian, Racine, empty because his characters did not emerge from daily life, and he lauded Proust for having captured the earthly world [33,34]. Auerbach "democratized" George's search for the hero via the "everyday tragic" and rechanneled Heideggerian "everydayness" via Vico, rendering it more sociocultural, less existential.

If Vico made a democratic redirection of "everydayness" possible, Auerbach's politics remained unclear, until National Socialism forced him to clarify it. Marxist literary critic Walter Benjamin (1892-1940) and philosopher Ernst Bloch (1885-1977) were his houseguests in the early 1920s, but his cultural politics was not leftist. His student, literary historian Werner Krauss (1900-1975), remembered him as a liberal nationalist. "You know me sufficiently ... to realize that I can understand the motives of your political views," he wrote historian Erich Rothacker when the latter joined the National Socialist Party [35]. "It would pain me much, ... if you wanted to deny me the right to be a German." Until the Nazi triumph, however, the temptations of George's "secret Germany" (which 
included intellectuals of Jewish origin) and of Heidegger's call for the authentic were great. Only when the political order collapsed, and Auerbach faced exclusion as a Jew, did he affirm, elliptically, via Christianity, the socially progressive bent of "everydayness"- and his own inclusion.

In 1929 Auerbach published Dante: Poet of the Secular World [36,37]. His book portrayed Dante as a transformative realist poet, who broke with allegory and brought out human character-concrete and historical. In The Divine Comedy, disembodied spirits in Hell emerge as tragic personalities, as if still alive, Cato, a pagan and a suicide, guards Purgatory's gates (and not a Christian saint, as the secular empire was the fount of justice). To Auerbach, Dante captured and transformed classical and Christian literary genres, and created new possibilities for literary realism [38].

Plato was notoriously suspicious of mimetic reality, poetic or artistic, and Aristotle, considering tragedy the noblest genre, "states very clearly that [it] must not represent [reality] as it comes to us, in its apparent disorder and disunity [but as] a correction of actual events, a happening superior to actual happening" [39]. Classical tragedy depicts "the hero's final struggle with his destiny, [and it] so divides and consumes him that nothing remains of his personality but his age, race, class and the most general traits of his temperament" [40]. But with Christ and the crucifixion-that "problematic and desperate injustice of an earthly happening"- "the drama of earthly life took on a painful, immoderate, and utterly unclassical intensity" [41]. Gospel narratives, focusing on Jesus' life and leading to the Passion, captured this historical drama. Christianity opened up new mimetic possibilities, enabling new forms of literary representation.

To be sure, Christianity relegitimized the earthly world only within the framework of eschatology and otherworldly justice. Neoplatonic efforts to allegorize biblical narratives repeatedly tested Christianity's earthly character. But realism persevered, and Dante repossessed, reshaped and pushed it further. Envisioning a "happy end" to his otherworldly tour, and using the "vulgar" vernacular, Dante, misunderstanding Aristotelian criteria, felt compelled to call his masterpiece a comedy. Truly, The Divine Comedy endowed the earthly world with a tragic vision of humanity that would not vanish even when secularization did away with Christian eschatology.

Dante served as Auerbach's habilitation under philologist, medievalist and Romanist, Leo Spitzer (1887-1960). With Spitzer's endorsement, and the support of Germany's most eminent medievalist, Karl Vossler, Auerbach was appointed, in 1929, to the Marburg chair in romance languages, vacated by Spitzer (who had moved to Cologne). Auerbach arrived in Marburg the year after Heidegger had left. Philosophers Hans-Georg Gadamer and Karl Löwith and theologian Rudolf Bultmann were on the faculty - the last two were close colleagues - and Marburg was thought to have a fairly liberal mandarin culture. The Auerbachs would remember their Marburg years as a golden age-the time when Erich was a full professor (ordinarius) surrounded by gifted students and colleagues, and they lived in a congenial German milieu.

These were also the turbulent years of the Nazis' rise to power. The Marburg student associations were, as elsewhere, the Nazi avant-garde. Auerbach did his best to distance himself from politics and, in 1932, enjoyed a summer vacation with a convertible in Italy. Historian Matthias Bormuth observes that Auerbach's 1932 "The Writer Montaigne" drew the contrast between Christian martyrdom and Montaigne's inner solitude (Einsamkeit), and diverged from Mimesis by sympathizing with Montaigne's withdrawal from public life to his home [42,43]. Feeling vulnerable as an intellectual of Jewish origin seemed to have only reinforced Auerbach's mandarin proclivity to opt for inner freedom 
when politics was becoming oppressive. Personal martyrdom was never an option for him but, in 1932, the ideal itself, which would become a subject for contemplation and admiration with WWII, still seemed remote, intangible.

Other German humanists, in contrast, took an open political stance. They established an important context for understanding Auerbach's work and politics. Leading romance philologist, Ernst Robert Curtius (1886-1956), published in 1932 a call for reconstituting a new Christian humanism against National Socialism and communism [44]. Curtius was both a literary critic and a medievalist, a Protestant fascinated with medieval Catholicism. He introduced T. S. Elliot to Germany, and familiarized the Germans with English, French and Italian literature. He regarded himself a German cosmopolitan and a European: "My conviction is cosmopolitan (not internationalist)," he said, to distance himself from socialist internationalism, "European on the basis of impartial ... national (not nationalist) feelings" [45].

As a leading conservative proponent of German-French reconciliation, and a member of international Catholic networks, as the Europäischen Kulturbund, Curtius inveighed against nationalism and secularism, and called for an intellectual elite to lead a cultural revival grounded in a shared European Christian culture. "Limiting the French message to Enlightenment and Revolution overlooks that France has long been the most Christianized European nation [and] ignores the best ... in the French spirit [and] tradition" [46]. He attacked sociologist Karl Mannheim and secular Jews for their historicism, relativism and skepticism, and for their refusal to adopt Christianity, humanism and Deutschtum [47,48]. The Jew became signifier for hated modernity but this was not simple antisemitism. Curtius' model for cultural renovation was none other than Hugo von Hofmannsthal, the icon of European Catholic cosmopolitanism.

Auerbach and Curtius shared much. Both represented a younger generation of romance philologists who expanded into literary criticism, ranging from classical to medieval to modern. Both were German humanists drawn to Dante, French literature and high modernism-Joyce and Proust. Both were German cosmopolitans, committed to a Christian European culture and adverse to the German nationalist denunciation of France as a Negernation. Both were rooted in "Europe of nations," now threatened by ethnonationalism. But Auerbach did not share Curtius' deep hostility to modernity and could not but sense that drawing Christian culture's boundaries threatened Jews like him. His response to Nazism was more demure and oblique than Curtius' but also more progressive. If Curtius turned to Catholic France, to contemporary poets Paul Claudel and Charles Péguy, Auerbach turned to republican France and nineteenth-century French social realism. He folded German romanticism into French realism, and declared the French the most authentic realists, European culture's peak achievement. Like other humanists, he sought to build a European culture on French-German affinities, a bulwark against Nazism, but his culture was more democratic and liberal.

Auerbach's 1929 inaugural lecture at Marburg on Dante and the Romantics recouped his past work for his new interest in modern realism: He recounted the discovery of Dante by Hegel, Schelling and Vico and argued that it reinforced the realistic bent of Romanticism [49]. As he was teaching French literature in Marburg, he noticed that the French realists followed a pattern he had observed in Dante, a pattern he now called Stilmischung, the "mixing," or merging of styles through the everyday tragic. Realism ended the classical Stiltrennung (separation of styles) by breaking the decorum rules designating the appropriateness of style (and genre) to subject, separating noble tragedy from lowly 
comedy. In his 1933 "Romanticism and Realism," Auerbach claimed Stendhal and Balzac, the great French realists, as inheritors of the Romantic tradition of Innerlichkeit (inwardness). Everydayness emerged as central for the Romantics and realists alike, and both rejected French classicism and formalism, with their elitist presumptions. Tragic realism reflected egalitarianism in the aftermath of the French Revolution. The French may have led the trend, but they built on German Romanticism [50].

If The Divine Comedy represented a perfect fusion of styles, French classicism, a child of French absolutism, was its opposite, a combination of laicism and hierarchy. Auerbach's 1933 essay on the emergence of the seventeenth-century French literary public reflected his hostility toward classicism [51]. The essay dovetailed with contemporary scholarly interest in court culture and the French bourgeoisie, such as expressed in the works of Bernard Groethuysen and Norbert Elias [52,53]. Throughout the seventeenth century, a powerless aristocracy and an alienated bourgeoisie competed for cultural leadership, the former acquiring empty manners, the latter counter-posing salon to court, and claiming that honnêteté (integrity) could be had by all (but the common people). But, to Auerbach, the emergent urban public and aristocratic court alike were superficial. Absolutism had a stifling effect on public life and culture.

In contrast, nineteenth-century social realism was the secular equivalent of Christian universalism. In "On the Serious Imitation of the Everyday" (1937), Auerbach presented Flaubert's Madame Bovary as an ultimate expression of "existential realism" that probed the depth of being-in-the-world. The imitation of everydayness transcended the classical separation between tragic and comic, between Racine and Molière, and, for the first time, applied a sophisticated psychology to daily life [54]. Rousseau was a central figure in the development of the new literary sensibilities, which reflected the democratization of French society in the aftermath of 1789 and 1848.

In constructing French absolutism, court and classical tragedy as a counter-model to historical Christianity, democracy, and mixed literary genres, was Auerbach thinking of 1930s Germany? He was too sensitive a historian not to recognize the gap separating racist populism and ethnonationalism from aristocratic hierarchy and royal authoritarianism. Yet, in the aftermath of 1933, he developed deep suspicion of abstract norms and heroic ideals, of myth and legend, and of hierarchies, and the suspicion converged with his contempt towards "the dreadful inauthenticity of 'blood and soil' propaganda" and Nazi racial hierarchy that made exclusion of the Jews from European culture possible [55]. Against classicism and racism alike he posed Christian authenticity: historical truth (contrasted with myth), daily life, egalitarianism, the dignity of the oppressed. Racism was inauthentic. There were nations, they could be ethnic, and they had each a unique cultural character. But German Jews, however different racially, were German because they shared in a German European culture inheriting the Judeo-Christian legacy.

\section{3. "Figura" and Exile: Christian Typology and Jewish Emancipation}

This culture had now to go into exile. As a decorated front soldier, Auerbach escaped the first wave of academic dismissals of Jews in the spring of 1933. He attempted, to the very end, to keep a low profile and ride the storm, and advised others to do the same. He told the Romanische Forschungen editor, Fritz Schalk, who was under attack by Nazi students at Rostock, to hold his nerves, not to provoke the students, and he added: "Something of what the youth want is right. We should take the 
wind out of their sail by accomplishing it better and in a different fashion" [56]. What Auerbach found acceptable in Nazi demands is unclear, but Leo Spitzer, who had lost his Cologne position in April 1933 and went to Istanbul University, thought that Auerbach betrayed the tribal "feeling of solidarity in times of sudden misery" [57]. Auerbach postponed as long as he could the mandatory pledge of allegiance to Hitler, but, on September 19, 1934, he took the oath to retain his job. Increasingly aware of the untenability of his position, he shifted his teaching duties to his assistant, Werner Krauss. On leave in Italy in September 1935, he grasped immediately the implications of the Nuremberg Laws, and began looking for a position abroad.

His suspension came quickly in mid-October. Marburg was determined not to begin the new academic year with Jews on the teaching faculty. Auerbach inquired with the Warburg Institute in London but they could offer no help. Preferring Europe to the U.S.-Palestine was never consideredAuerbach competed with another German Jewish cosmopolite, Victor Klemperer (1880-1960), for a professorship in "Western European philology" at Istanbul University. Klemperer was, like him, a decorated war veteran and a romance philologist who had just been dismissed from his Dresden position. With a letter from Italian philosopher Benedetto Croce (who had collaborated with Auerbach on the Vico translation), and with support from the previous chair holder, once again Spitzer (who was now going to the U.S.), Auerbach prevailed. He requested, and received, a leave from Marburg and permission to take residence abroad. He went to Switzerland to brush up on his French and, in September 1936, showed up for his new job in Istanbul, the family following him in November. The assimilated Klemperer, married to a non-Jew, survived the Holocaust in Germany by a thread. His Diary, published half a century later, Ich will Zeugnis ablegen bis zum letzten (I will bear witness to the last), would rivet Europeans [58]. He, a cosmopolitan German European was the true German, not the Nazis, he said. "How did you manage to survive in Germany?" wondered Auerbach in a postwar letter to Klemperer [59].

Auerbach was one of about 130 German exiles to whom Turkey provided refuge from Nazism. Istanbul Üniversitesi was a traditional Islamic school reorganized, in 1933, as a university, as part of Mostafa Kemal Atatürk's Westernization and secularization effort. The education ministry dismissed many teachers, and looked for Europeans to head newly established departments. For obvious reasons, Nazi Germany provided the largest pool of applicants. At one time or another in the 1930s, Istanbul University had on its staff such future luminaries as economists Fritz Neumark, Wilhelm Röpke and Alexander Rüstow, mathematician Richard von Mises and philosopher Hans Reichenbach (the last two connected with the Vienna Circle network), and philologists Leo Spitzer and Auerbach [60]. Most were of Jewish origin but they brought with them non-Jewish German assistants, and, together, they constituted a German exile community on the Bosporus. They turned German humanistic education into a model for Turkish higher learning. Almost all left eventually, some before the war, for the U.S. and Switzerland, others returned to Germany after the war. In the interim, they shaped a generation of Turkish scholars, and participated in Europeanizing the Turkish university [61,62].

Auerbach felt ambivalent about Turkey's Westernization. As department head, he was responsible for the curriculum of European language instruction, wrote a French textbook, and helped set up a library catalogue. He needed to lay the ground for all fundamentals of university education and negotiate constantly with a recalcitrant bureaucracy [63]. He was not an administrator by nature, and, unlike Spitzer and some of his friends, he attempted no Turkish immersion. As a German Jewish 
professor teaching French to Turks, he felt alienated. He despised Turkish nationalism and thought the nation-building project destructive: an assault on multiple old cultures, an invented barbarous language, and a fictitious secular identity [64,65]. The refugees, he was aware, took over positions of Islamic scholars deposed, like them, by secular nationalists and were resented by large Turkish constituencies. Vico's world of nations was running amuck. Auerbach held copycat modernization and nationalization from above responsible.

Istanbul was a war haven but it was exile, and "the bread of exile," Auerbach quoted Dante, "tastes salty" [66]. Like other German émigrés, he lived in the picturesque suburb of Bebek, riding the tram to the university in the Beyazit district. He admired the city's cultural legacy, especially the old architecture (and despised modernized quarters), and he enjoyed the colorful scenery and gastronomy. He sent his son Clemens to an international school. The low cost of living made a decent, if modest, life possible, even as his resources were dwindling during the war. But he felt uprooted. He never applied for Turkish citizenship. Once his German travel documents expired in 1941, he had no clear legal status. The German government was watchful over Germans living in Turkey, regarding them as potential cultural ambassadors for the Third Reich. Nazis infiltrated émigré clubs and took them over. In 1943, Istanbul University established, over émigré objections, a German department under a Nazi. Upon arrival in Istanbul, Auerbach had signed that he would not engage in political activity (so as to protect Turkish neutrality). A 1939 German report bemoaned that Istanbul University had been judaized (verjudet) and the director of European languages was a non-Aryan, a former Marburg professor who could not be trusted. The report urged the expatriation of all non-Aryan émigrés. Auerbach was not completely safe [67,68].

Exile came as a shock. Auerbach found himself excluded from the German European culture in which his scholarship was grounded and of which he was an exponent. German journals were close to him, and, in romance philology, there was really no non-German equivalent. His path-breaking essays during his Turkish sojourn - two of them in French and English, languages in which he had never written-were published in Finnish, Italian and U.S. journals and in new Turkish series. A Swiss publisher brought out Mimesis in 1946. Istanbul University had no academic library. Angelo Roncalli, future Pope John XXIII and, at the time, the Papal Delegate in Greece and Turkey, opened to him the library at the Dominican monastery in San Pietro di Galata, which had the complete Patrologia Latina [69]. But the sparse and occasionally incorrect scholarly references in his essays made his isolation evident. He was homesick before his first year in Istanbul was over. The family took its summer 1937 vacation in Germany. While in Berlin, Clemens was summoned by the Gestapo to check on his residence, yet Marie still dared to return the summer after to finish family business. On the way back to Istanbul, the Auerbachs travelled via Salzburg, Trieste and Athens, clinging to the German European culture they inhabited, refusing to accept their exile [70].

Yet, experiencing humiliation and exclusion, observing the collapse of the European order from the margins of the continent, and witnessing Turkey's modernization, Auerbach acquired a measure of distance from European culture and a more global perspective on it. He sensed that he was witnessing Europe's dissolution, and the experience was painful and sobering. Already in the fall of 1935, upon reading, in the Neue Zürcher Zeitung, a section of Benjamin's reminiscences of his Berlin childhood around 1900, Auerbach spoke of "memories of a home that vanished so long ago!" [71]. His renewed correspondence with Benjamin disclosed nostalgia, mourning and redemptive hope for European 
culture, all mixed. He retained just enough providentialism — or was it after all Hegelian historicism?to assume a moral pattern to history, from which one could derive instruction for action. The triumph of National Socialism and the end of Jewish emancipation upset this pattern, and he was at a loss, searching for sources of spiritual renewal for European civilization.

The challenge is not to grasp and digest all the evil that's happening — that's not too difficult—but much more to find a point of departure for those historical forces that can be set against it. To seek for them in myself, to track them down in the world, completely absorbs me. The old forces of resistance-churches, democracies, education, economic laws - are useful and effective only if they are renewed and activated through a new force not yet visible to me [72].

Where was he to turn in exile, searching for this new force? Traditional Jews could turn to Jacob, their wandering ancestor, and seek comfort and instruction in his travails. As secular a Jewish intellectual as sociologist Norbert Elias composed, in 1940 in a British detention camp, "The Ballad of Poor Jacob" that retold the wandering Jew story as a parable for the universal refugee: "And once again he walked without money a little further into the wide world" [73]. Exile, as experience and motif, still tied Auerbach to his Jewish heritage: In Mimesis, he noted in passing that "Jacob really [was] a refugee." He apparently lectured to the Istanbul Jewish community on educational issues (something he was unlikely to do in Germany) [74]. But Jewish sources and traditions were a closed book to him. One wonders what Auerbach could say to the Jewish community.

Instead, Auerbach turned to Augustine and Dante, whom he considered the great spiritual and literary innovators of the West. The topoi of his exile essays were the Passion, sermo humilis and figura: The Passion's shaping of Western emotions, Augustine's refashioning of sermo humilisScriptures' lowly style when speaking of the sublime - and Dante's deployment of figura, typology, as a bridge between the historical and the transcendent [75-78]. All provided models for Christian engagement in the world. All were grounded in the Incarnation and the Passion-in Christ human and divine. Werfel believed as a Catholic in the cross and remained Jewish as an act of solidarity with his people. Auerbach was just enough secular not to believe in the miracle of the cross, and remain Jewish by default, but more than enough cultural Christian to uphold the event and the biblical narrative recounting it as world transformative-conveying symbols and ideals that nourished Western civilization. He sought the guidance of Augustine and Dante as to how to translate theses ideals into Western renovation.

Augustine, Auerbach thought, lived like him the dissolution of a civilization - that of the Western Roman Empire. He remolded Latin to make culture accessible to the common people, "fill[ing] this language with new content and giv[ing] it a special style ... sermo humilis" [79]. The transformation of rhetoric, accompanied by Augustine's new psychology and ethics, shaped the Western understanding of the individual and the literary possibilities for expressing it. Still, Augustine was of limited use to Auerbach. His view of history as an inconsequential interim between Christ's first and Second Coming, of earthly life as a sojourn, a pilgrimage, and an exile from the Lord, and of the Roman Empire as a pact of criminals ran contrary to Auerbach's earthly Christian world and to his experience of exile [80]. Augustine would never recognize Auerbach's "everyday tragic."

Dante presented a stark contrast to Augustine. The Florentine exile's views on Christian and civic life, like Auerbach's own, left no place for permanent homelessness. Auerbach's October 1938 letter to 
medievalist Karl Vossler suggested that he began viewing his own exile via Dante's protagonist in The Divine Comedy [81,82]. He found in Dante two models for engaging the world: the first, exemplified in "Figura," drew on the Christian legacy to transform literary style and culture, the second, exemplified in Mimesis, shaped a cosmopolitan literary public to become its spokesperson. Dante showed how the predicament of exile and the crisis of European culture could be overcome through cultural innovation. Standing at the apex of medieval culture and presaging the Renaissance, he sustained Auerbach's hope, prior to WWII, of cultural restoration.

Whence, Auerbach wondered, The Divine Comedy's transformative power? How did Dante manage, historically, to break with both Christian allegory and the classical decorum and create the everyday tragic? Dante's and medieval literature's recovery of a patristic mode of biblical exegesis, figura, or typology, which entailed an omnitemporal conception of history that superseded cyclical and linear ones, was Auerbach's answer.

Figural interpretation establishes a connection between two events or persons, the first of which signifies not only itself but also the second, while the second encompasses and fulfills the first. The two poles ... are separate in time, but both, being real events or figures, are within time, within the stream of historical life [83]. Moses and Christ ... are related as figure and fulfillment [but] Moses is no less historically real because he is a ... figura of Christ, and Christ, the fulfillment, is no abstract idea but also a historical reality [84].

Dante could so skillfully make historical figures express transcendental meaning because medieval literature capitalized on a millennium old typological understanding of history and text, paving the way for The Divine Comedy.

Auerbach had not known figura's universe well prior to his exile. He was neither a classicist nor a patristic scholar by training but a romance philologist, a Dante and Vico scholar who moved to work on French literature. His study of Dante required that he reconstruct historically the mimetic problem and its Christian transformation but he had no detailed knowledge of classical and patristic sources beyond the education of a humanistic scholar. In exile, he studied patristic literature intensively and felt moved. He found in it consolation and encouragement, and the experience would shape Mimesis. In the postwar years, he would still be enraptured by the survival of Christian culture through the early middle ages but the focus would no longer be patristic. Figura constituted the intellectual and emotional world of Aurbach's Turkish exile.

Figura signaled also Auerbach's turn to Catholicism. In 1921 he had declared himself a Prussian Jew (rather than simply a German Jew), intimating his preference for Protestant culture. But with the Nazi triumph, cultural Protestantism, wholly invested in the nation state, appeared bankrupt, and its protagonists were commonly rushing to reconcile with the new regime. Auerbach's method continued to reflect his Protestant training, but his vision, from the mid-1930s on, showed significant marks of the Catholic understanding of modernity and secularization, and he expressed admiration for medieval Christendom [85]. Already in his 1933 essay on the seventeenth-century French public, Auerbach offered a rudimentary theory of secularization, inspired by Catholic philosopher Étienne Gilson (18841978). The emergent public, designed to distance the bourgeoisie from "everyday life," was the moral agent behind classical tragedy's revival. Like Descartes' epistemological subject, the public reflected de-Christianization, a disavowal of the divine in the mundane. National Socialism's anti-Christian turn mimicked early modern absolutism. 
"I belong to the Jewish community," said Auerbach in 1935, "but my work has been engaged for many years with Christian theology, especially of Catholic circles (Guardini, Gilson)" [86]. Romano Guardini (1885-1968) was a leading German Catholic scholar and an anti-Nazi public intellectual. Auerbach's protagonists for the next decade would resemble Guardini's: Augustine, Dante, and Pascal. Luther was nowhere to be seen. Typology was primarily a Catholic affair, first of Gilson, and then of Jesuit theologian, Henri de Lubac (1896-1991), who assailed antisemitism as anti-Christian and would inspire Vatican II $[87,88]$. For a cultural Christian and a German Jew, it was not unreasonable to sense, in the 1930s, that Catholic culture offered greater space for Christian Jews than Protestant one. Moving between cultural Protestantism and Catholicism, Auerbach made typology a Jewish project.

"Figura" provides a history of typology as a literary and artistic form, from the Roman poets to patristic literature to Dante. Auerbach began "Figura" with the Hellenization of Roman education in the first century BCE and the transmission of Greek literary and philosophical concepts, such as schẽma, into Roman culture. He moved from republican era poets Lucretius and Cicero to imperial era poets Virgil, Catullus and Ovid, and from them to architecture, jurisprudence and, above all, to Quintilian's rhetoric. The poets were fascinated by "the play between model and copy, the changing form, the deceptive likeness of dream figures" [89], the architects contemplated models to emulate, and Quintilian designated by figura multiple literary tropes, product of the metaphoric imagination that enriched rhetoric. Figura remained primarily literary, of interest to limited intellectual circles.

The advent of Christ, the crucifixion, and Christian sacraments changed radically figura's meaning and significance [90]. Jesus' disciples naturally looked to the Hebrew Bible for prophecies figuring his advent. The Greek typos, used in early accounts to designate prefiguration of events and persons connected with Christ, devolved into the Latin figura, now combining biblical "prophecy" with classical "representation." "Figure" turned into "prefigure" (of the New Testament by the Old), the literary notion became historical, designating real events and persons [91]. For Paul, on his mission to the Gentiles, the Hebrew Bible turned "from a book of the law and history of Israel into one of a unique great promise and a prehistory of Christ.... What the Old Testament thereby lost in the efficacy of its law and in the autonomy of its national history, it gained in concrete dramatic actuality" [92]. "[T] o the newly converted peoples, [it gave] a basic conception of world history," "its integral teleological view ..., the providential order ... captur[ing] the[ir] imagination and innermost feeling ... with its living historicity" [93]. Figura became constitutive of the Christian conception of reality and history. It represented "a fresh beginning and rebirth of creative powers" [94].

Christian typology combined historical depth with popular reach. The future was concealed yet embodied in persons, who were not historically contingent but signified universal and eternal meaning; God himself was incarnated in figures and sacraments. Allegorical, ethical and spiritual interpretations, rendering biblical persons and events symbolic, provided an alternative to typology. From Jewish philosopher Philo to Church Father Origen and the Alexandrian School to medieval times, allegory coexisted with figura. But allegorization, insisted Auerbach, remained an elite project, whereas Christian typology, phenomenal and historical, expanded the reach of figural thinking to the socially downtrodden, bringing together high and low. Beginning its triumphant march in patristic literature in the third century with Tertullian, typology became hegemonic with Augustine in the fourth century. Both Tertullian and Augustine were staunch realists, who rejected allegorical spiritualism. "When you hear an exposition of the mystery of Scriptures telling of things that took place," 
admonished Augustine, "believe what is read to have actually taken place ... lest ... you seek to build in the air" $[95,96]$.

Medieval allegory was doctrinally one of the fourfold sense of Scriptures but figura predominated, insisted Auerbach [97]. Separating typology from allegory, Auerbach rebutted the common view of The Divine Comedy as allegorical. Virgil, who guided Dante through Hell, and Beatrice who welcomed him in Paradise were figures, not allegories, real historical persons, not theological principles. An embodiment of poetic eloquence and worldly virtues-liberty, wisdom, justice and piety-Virgil, the fullness of earthly perfection, had the capacity to guide Dante to the threshold of insight into the divine. Beatrice, sent by divine grace to guide Dante (and humanity) to salvation, incarnated revelation, but her relationship to Dante could not fully be explained by dogmatic considerations. She was also his beloved Florentine, and their lives did intersect. Every mythical or historical figure in the Comedy had a meaning connected with what Dante knew about their life. Virgil was not "virtue" or "reason," rather, the literal meaning figured the theological, and the theological confirmed and fulfilled it, both meanings having a place in a providential history [98].

"Figura" ended on a rather minor note that seemed to diminish the brunt of Auerbach's tour de force. To his earlier call to revisit allegory and figura in medieval literature, Auerbach now joined the observation that figura's history showed how a word could develop into a world historical situation. Paul's mission to the Gentiles endowed the classical concept with structures that would shape the late antique and medieval intellectual worlds [99]. Viewing Paul's move from national to world religion (Judaism to Christianity) as the crucial turning point in history was in line with the common Christian view, but it did not elucidate figura's implications for Europe. How did Christian realism shape modern culture? Auerbach hinted that medieval literature already contained the origin of secular realism but he shunned any suggestion as to how secularization had taken place. His caution reflected his genuine bewilderment about the origins of the European crisis - he sensed that secularization prepared the way but he just did not know how.

All the same, "Figura" did have a political agenda, if not as open as the academic one. Academically, Auerbach intervened in medieval studies, urging scholars to distinguish between allegory and typology, between the diversity of literary metaphors and figura. Typology was, he insisted, the quintessential Christian mode, and Christian realism was mainstream. But his professional intervention was politically loaded. He discovered figura just as the exclusionary power of race made him painfully conscious of his Jewishness. "Figura" stuck a position in German debates on the "Jewish" character of the Old Testament. Auerbach sought to renegotiate Jewish membership in German European culture, i.e., Jewish emancipation, by highlighting the Jewish origins of European culture.

Thinkers ranging from liberal Protestant to Nazi dissociated the New Testament from the Old. The liberals aimed to rescue a Christian mission - universal or national—from "Jewish particularism," the racists, most radically the German Christians, to establish Aryan Christianity. In his 1933 Advent Sermon, Munich Cardinal Faulhaber tepidly defended the Old Testament as holy, if inferior, to the New [100]. Reformed theologian Karl Barth (1886-1968), a leader of the anti-Nazi Confessing Church, affirmed, in contrast, the unity of revelation: The Old Testament pointed forward to Christ, the New Testament backward. But for him, too, the Old Testament had no value as a book about Ancient Israel: "For us the Old Testament is valid only in relation to the New. If the Church has declared itself 
to be the lawful successor to the Synagogue, this means that the Old Testament is witness to Christ before Christ but not without Christ" [101,102].

Against this chorus, Auerbach underlined the historical continuity between the Old and New Testament by using typology. He reargued the case for the Old Testament against the like of Harnack who wished to de-canonize it. "It was not until very late," he said acerbically, "that Europeans began to regard the Old Testament as Jewish History and Jewish Law" [103]. He uncovered a patristic and medieval interpretive mode that superseded the progressive conception of history. Still, precisely because he wished to sustain Jewish integration, and, in 1938, still held hope for Germany, he never took the Barthian turn of Jewish rebels of his cohort, who radically separated reason and revelation, challenged their parents' optimistic historical theology, and affirmed authentic Jewish identity. He would not commit himself to the Catholic critique of Enlightenment and the nation state, either. Barth, the Catholics and Auerbach agreed that the Old and New Testament were of a piece, but Barth's antinationalist, anti-historical, unearthly Christianity left Jews forever as the Other, and the Catholics were profoundly antimodern. Liberal histories brought Jews and Christians so close to each other that Auerbach would not give them up for Barth's Christocentric history or forgo modernity. He would rather work through history than through theology, negotiate with Harnack rather than with Barth, argue with prejudice rather than concede incommensurable truth and otherness, heal rather than reject modern life.

"Figura" was a desperate attempt to salvage emancipation and German Jewish cosmopolitanism through a shared Judeo-Christian tradition. It allowed only for a diminished space for Jews, and, indeed, it is not clear that they could any longer be recognized as Jews. In the debate between Judaism and Christianity, Auerbach accepted the Christian argument-Christianity superseded Judaism. A December 1941 letter to an Istanbul colleague, Alexander Rüstow, made his view about Judaism's obsolescence clear: Jewish life had long been reified, and Jews were leading a ghostly existence [104].

The uncanny feeling Judaism evokes, the sense that it is laden with a curse, grew, and became concrete, through the role the Jews played in the rise of Christianity. Christianity originated with the Jews but they rejected it, so that the mission reverted to the Gentiles, forming a contrast between Jewish Law (now but a shadow and a ghost) and the fulfillment of Christian Grace (which disempowered the Law) [105].

The Jews had had no authentic spiritual life since the time of the Prophets but they still presented the spectacle of a people living apart in exile, attached to their ancestry. Through the ages, they survived as a minority, subject to hatred and persecution, while other nations, with viable political life, vanished. The Enlightenment constituted a break, removing the taboo against the Jews-forever. Modern antisemitism was a byproduct of nationalist struggles, an opportunistic endeavor to use atavistic relics to reinforce exclusion, historically hopeless and meaningless. The Jews were part of European culture, and antisemitism had no object, purpose or prospect. It was "a side issue." In time, it would disappear [106]. The Jews may meanwhile suffer but they should be thankful for the role of martyrs for humanity - a role they did not deserve - that fell in their lot.

This extraordinary statement, made at a time when, unbeknownst to Auerbach, Soviet Jews were already being shot in the tens of thousands, and Hitler was completing the plans for destroying all of European Jewry, provides precious insight into Auerbach's worldview. It reflects crude Christian supersessionism, incredible optimism about Jewish emancipation, a profound misreading of 
antisemitism, and an avowal of the Christian martyr role for the Jews. Auerbach's ignorance of Jewish typology was grounded in the conviction that postbiblical Jewish life was not part of European history. The Jews became part of Europe only when the Enlightenment made their integration possibleand no longer as Jews: "Anything significant that came out of the Jews was absorbed by the host nations" [107]. Jewish history — if such existed — was not part of European history.

Jewish ethnic survival was for Auerbach a source of puzzlement — of wonder (and perhaps hidden pride) mixed with apprehension about their "uncanny" existence. Like philosopher Karl Popper, Auerbach had no doubt that it was high time for Jewish life to end-for the Jews to become part of Christian Europe. Popper imagined the culture integrating the Jews as avowedly secular, its relationship to Christianity tenuous; for Auerbach, it clearly bore the marks of secularized Christianity. The National Socialist attack on the Jews was only significant for its denial of humanity, and the Jews acquired their universal role as Christian martyrs. Christian martyrology became paradigmatic of the Jewish experience, and Auerbach, captivated, devoted to it increasing attention during and after WWII. The murdered Jews were integrated into European civilization - as (undeserving) Christian martyrs.

"Figura" was emblematic of European history integrating the Jews as Christians. Auerbach's turn to Catholicism facilitated a transformation of cultural Protestant narratives but he retained them, however altered, because he did not wish to give up on modernity or emancipation. He modified Harnack by skipping over Marcion (who rejected the Hebrew Bible), highlighting Tertullian and Augustine, and ending with Dante rather than with Luther or modern Protestantism. Dante became a start-point of modernity, of secularization that would de-eschatologize Christian history but absorb Dante's vision of humanity, leaving a universal history to be shared by Christians, Jews and all. This universal history, however, still bore its Christian marks - it did not permit Jews to remain Jews. A Christian humanist who remained Jewish, Auerbach constructed a narrative of Western civilization that appealed to the highly acculturated German-Jewish intelligentsia — and today's Europeans. "Figura" has become his most famous essay, and virtually canonical.

\section{Mimesis and the Holocaust: The Jewish Origins of European Civilization}

European restoration, German Jewish cosmopolitanism and emancipation all depended on the survival of Vico's world of nations. With the collapse of Europe in World War II, Auerbach lost hope for them. Mimesis, written (according to Auerbach) between May 1942 and April 1945, at the height of the war and the Holocaust, reflected a change of orientation. As a refugee without national identity on the outskirts of a devastated continent, Auerbach no longer wrote as a German European. His previous audience was gone, at least for the war (and he suspected forever), and he did not know who his prospective audience might be, or what shape postwar Europe might take, indeed, if it, and he, would survive at all. He had to refashion his authorial identity and imagine a new audience. "The Jewish refugee in Istanbul," says Carl Landauer, "very much the outsider, re-established himself as an insider" by reconfiguring both the European audience and himself as members of the Western tradition [108].

Deploying a style suggested by high modernist novels, Auerbach began writing as a cosmopolitan spokesperson for a "European classico-Christian literary culture" [109,110]. He appeared as a panEuropean, at once a Christian humanist and a modernist, drawing the boundaries and charting the legacy of Europe for a cosmopolitan audience. In exile from Florence, Dante proclaimed "the world is 
my fatherland," and the Swiss historian, Jacob Burckhardt, echoed him: "My country is the whole world" [111,112]. Auerbach joined this lineage of aspiring cosmopolitans, imagining "a European world in which he was at home" [113].

Mimesis charted the history of Western literary styles and their representation of reality in nineteen (and, in later editions, twenty) exquisitely crafted essays on the classics of Western literature. Auerbach began with the Odyssey and the Hebrew Bible, continued with the classical Roman poet Petronius and the New Testament, moved on to the fourth-century historian Marcellinus Ammianus and Augustine, and captured the transition from the late antique to the medieval with Gregory of Tours' History of the Franks. He skipped half a millennium to the medieval epic of Roland, the romance of Yvain and "Adam and Eve" Christmas plays, paid homage to Dante in the unforgettable "Farinata and Calvacante," and showed Boccaccio and the fifteenth-century chivalrous chronicler, Antoine de la Salle, negotiating the Renaissance and the waning middle ages. The sixteenth-century giants, Rabelais, Montaigne and Shakespeare (and, in later editions, Cervantes) gave a measure of secularization, Molière and his critics displayed seventeenth-century French classicism, an Abbé Prévost 1731 sentimental novel paired with Voltaire's Candide and Saint Simon's Memoirs of Louis XIV's court marked an emergent Enlightenment, and Schiller and Goethe drew the German enlightenment's limits and their import for German realism. Mimesis concluded with three essays on modern realism, beginning, respectively, with Stendhal, the brothers Goncourt, and Wolfe, but comparing their works with other exemplars of French, English, German and Russian realism.

The format for Mimesis' essays was uniform: Auerbach opened with long quotation from the work, which provided the focus for his analysis. He tracked the uniqueness of the literary style and placed it in its life-world, accentuating comparable or competing literary modes. The book had no footnotes. The limits of the Istanbul library, Auerbach suggested, made writing a book covering three millennia possible but also dictated his textual focus and his daring construction of context. Mimesis had no introduction or conclusion to provide an overarching argument or context. Only a brief epilogue lent Mimesis a measure of coherence, offering an historical outline of the doctrine of styles. Critics complained that Auerbach's realism was impossible to pin down, as the meaning of reality kept shifting from epistemological (empirical and sensational) to sociological (class structure) to psychological (emotional state). Mimesis remained elusive.

As if to increase Mimesis' mystery, Auerbach made very few allusions, mostly oblique, to his own world - to National Socialism, exile and the war. Mimesis' opacity, joined by its aesthetic appeal and daunting reach and erudition, gave rise to a lively debate on Auerbach's narrative of Western civilization. Commentators have viewed Mimesis alternatively as literary Christology, Jewish philology, secular criticism, minority literature and literary modernism [114-118]. This much is clear: Postwar U.S. and European critics alike have found Auerbach enthralling, and his fame has been on the increase. Auerbach told a story postwar Europeans loved to hear. Mimesis did end up shaping the new cosmopolitan audience Auerbach imagined and became a charter for a new Europe.

Mimesis' focus remained, however, on the current European crisis. Auerbach offered clues to its origins by putting forward an ironic vision of secularization and a rudimentary theory of the failure of German literary culture. His leitmotif was the emergence of modern literary realism in the secularization of Christian realism [119]. Like Weber's story of capitalist rationality, Auerbach's secularization narrative was ironic [120]. Christian realism legitimated the earthly world, and the 
earthly world, in turn, diminished the divine. Dante never intended to dispel the enchanted life his Comedy depicted, but "Dante's work made man Christian-figural being a reality, and destroyed it in the very process of realizing it" [121]. Auerbach could not fully explain the secularization process but the vanishing of typology and the rise of historicism gave measure of it. He located several literary sites, notably among sixteenth-century authors, to show secularization happening. For Montaigne, "life on earth is no longer the figure of the life beyond. ... To live here is his purpose and his art" [122]. Modernity confronted an eclipse of the divine, loss of providential history, and an irreparable breach between the earthly and transcendental.

Auerbach found all secular substitutes to Christian realism falling short, unable to make up for transcendental loss. Neither historical progress nor aesthetic perfection or self-cultivation (Bildung) could make up for the dissolution of the bond between human and divine. But the French realists' social criticism and their grasp of the everyday tragic reflected a dignified literary sensibility, one appropriate to a secular culture undergoing democratization. Stendhal's narration in The Red and the Black of his protagonist's progressive disillusion with the Parisian elite gave realism its most authentic expression. Both the Flaubert generation's turn to aestheticism, to art for art's sake, and the realists' indifference, especially Zola's, to the transcendental were inadequate responses to bourgeois materialism, but they could not diminish the grandeur of their cultural and social critiques. The French realists gave a glimpse of lost Christian realism. The Christian humanist found in secular democratic realism the closest approximation to the original.

Humanism itself, however, came under scrutiny and revision. This emerged most clearly in Auerbach's critique of Goethe. Goethe confronted Germany's political fragmentation and conservative social order with equanimity. Historicism opened possibilities for literary realism by highlighting process and change but Germans could not look beyond their regional cultures. When the French Revolution raised the prospect of a democratic national culture, Goethe recoiled, reaffirmed his preference for the nobility and posed Bildung and the integrated personality as ideals. But a national culture required social engagement, not self-cultivation. Germany developed no realist literary tradition. When unification came from above, Germany found itself without a culture adequate to modernity's challenges. Thomas Mann was, in fin-de-siècle years, the first serious German realist, and, shortly after, World War I threw European realism into turmoil, from which it emerged with a fragmentary modernist style, unable to sustain a national culture. Nazism encountered no cultural barrier on its way to power. German humanism was implicated in the German catastrophe.

Goethe was the George Circle's hero, their model for fashioning the "self as character." Auerbach's critique of German culture represented a reevaluation of the circle, philological humanism and his own past [123]. Human perfectibility and aesthetic integrity were incompatible with a secular democratic age. They reflected refusals to pay heed to social deprivation and to come to terms with transcendental loss-harmonious personality was forever gone with the divine. Self-cultivation displayed overappreciation of classicism and the aesthetic and a failure at Christian humility. To make philological humanism more socially responsive, "Figura" and Mimesis underlined the limits of classicism, and Mimesis parted with scholarly style and emulated high modernism. Just as French realism responded to democracy, Auerbach's modernism responded to European turmoil and globalization. He held German culture responsible for democracy's failure but the challenge was global. The European nation state was approaching its end. Philological humanism had now to address a cosmopolitan public. 
French authors predominated in Mimesis, reflecting Auerbach's move from German to European cosmopolitanism. Not one German work provided the title or focus for any of Mimesis' chapters. "Romance literatures are more representative of Europe than ... the German," insisted Auerbach [124]. German humanists, like Curtius, shared his French and modernist sympathies, not to mention his Christian appreciation, but he parted with the national tradition in ways they never did. He was unique in his democratic vision of Christianity, in aligning realism and democracy, in rooting them in Christian realism, and in criticizing Bildung, humanism's fountain. His critique presaged postwar liberal theories of a German Sonderweg, a unique German path, divergent from Western liberal democracy. Postwar liberals, too, traced the roots of the German catastrophe in cultural authoritarianism and elitism and focused on German intellectuals' political irresponsibility. But Auerbach did not think he was exploring a Sonderweg. No national culture, he said, reached the height of French realism. The German failure had the most serious consequences but the crisis was European, indeed global, and it went to the heart of secular modernity.

Mimesis could offer no solution to the European crisis. Rechristianizing the secular world was no more possible than escaping Weber's iron cage of capitalism. Works such as Lukàcs' Theory of the Novel, emerging from Weber's Heidelberg circle and pre-WWI mandarin sociology, understood modern literary genres to be reflective of the breakdown of a holistic premodern world, the dissolution of Gemeinschaft (community) [125,126]. Mimesis updated them with consciousness of the end of Europe. Lukàcs and Auerbach upheld realism for its social consciousness, admired Mann, and censured German Kultur for the Nazi disaster [127]. But Lukàcs strove to break out of the iron cage through communism; Auerbach, a mild liberal, remained entrapped. To Auerbach, secularization, not capitalism, was the root of modernity's travails. Concern for the poor was at the heart of Christianity, but atheistic socialism could not undo transcendental loss, only reinforce it. Auerbach was permeated with Weber's tragic vision, reinforced by a Catholic sensibility of modern loss. His disposition toward European culture was a combination of nostalgia and criticism, detachment and engagement, depression and exhilaration.

One wonders how Auerbach could maintain this interplay of proximity and distance facing the Holocaust. But the murder of the European Jews is not mentioned even once in Mimesis and appears not to figure in Auerbach's European crisis. Postbiblical Jews vanish from Auerbach's narrative of Western literature. He made a special effort to ignore them: In discussing Shylock as a (non-) tragic figure, he overlooked his Jewishness. Contemporary readers find his silence so baffling that they strive to find clues to the Holocaust in Mimesis [128,129]. Is Auerbach's discussion of the binding of Isaac, the Akedah - a Jewish martyrology topos emerging repeatedly in Holocaust discourse - not a gesture toward the Holocaust [130]? Is the vindication of the Hebrew Bible against classical epic, of bound Isaac against Odysseus, destroyer of Troy, not a claim to Jewish spiritual superiority - and survivalover German might?

How one would wish! Mimesis did respond to the Jews' exclusion from European culture by showing the Jews as founders of this culture and challenging German affinity for the classical. Indeed, in no other Auerbach work is there such concern for the Hebrew Bible, such insistence on calling biblical authors (of the Gospels, too) "Jewish," and using the appellation Judeo-Christian for the emergent Western tradition. But neither the binding of Isaac nor the plea for the Old Testament was a Holocaust referent. Auerbach was ignorant of the Akedah typology [131]. He chose the binding of 
Isaac with an eye to the real world-making event, the "scandal of the cross" [132]. However much he defended the dignity and independence of the Old Testament, and sought to remain neutral on the Christian interpretation of the Akedah as prefiguration of the crucifixion, he absorbed the binding of Isaac into a Christian narrative of Western literature. Christian supersessionism reigned triumphant.

Moreover, Auerbach thought of WWII as a European and German catastrophe, not a Jewish one. He was writing Mimesis as representative of "European classico-Christian culture," not as a Jew. He had every apprehension that, were he to appear as one, he would not be recognized as an authentic representative. Biblical Jews were part of Western history, indeed, its founders. Postbiblical Jews became members only insofar as they were part of Christian civilization. Mimesis' pan-European space, and cosmopolitan audience, had no room for Jews, qua Jews.

Auerbach's strategy for Jewish integration via Christian culture remained the same even as his projected audience expanded from the nation to the cosmopolis. This was less than evident because Auerbach did not pursue openly Mimesis' agenda. Even his thrust against classical hegemony and promotion of the Judeo-Christian heritage remained camouflaged. The contents, or essay titles, would suggest a classical transmission line from Homer's Odyssey to Petronius' poetry to Ammianus' history. Not until medieval Christian drama did Auerbach place a religious text at the center of an essay, and this was the single essay in Mimesis where he did so. There was no biblical transmission line. The major works Auerbach used to control the classical - the Hebrew Bible, the New Testament, Augustine's Confessions - appeared as comparisons in essays dedicated to classical works. Christian typology, figura, did its work behind the scene. Not surprisingly, critics push Auerbach just a bit further-beyond what his intentions or intellectual resources would allow-by suggesting that he camouflaged a Jewish agenda under Christian rubrics. On the Jewish Question, however, Auerbach remained consistent from "Figura" to Mimesis: The Jews were to be integrated as cultural Christians.

The Old Testament became in Mimesis the central conduit for Jewish membership in the West. In the magnificent "Odysseus' Scar," Mimesis' opening chapter, Auerbach contrasted the two models of realism informing Western literature: Greek epic and the Hebrew Bible. The Homeric poem's elevated style, its rich and intricate description of worldly scenes, uniformly, completely and unmistakably explained, contrasted with the Bible's sparing use of language, its rough narrative accentuating aspects of characters and scenes, leaving much unexpressed, in the background, calling for interpretation. Biblical protagonists had inner psychological intensity and a grappling multilayered consciousness, while Homer's heroes never changed, and their emotions were laid bare in the foreground. Claiming absolute truth, biblical narrative constructed a universal history, however disjointed, to impart ethical and pedagogical messages, and events found their meaning in temporal connections. For Homeric legend, historical time, and truth, were inconsequential, and horizontal connections - a tightly and beautifully woven web-provided the meaning. The Homeric epic displayed everyday realism but "everyday" was confined to the idyllic home, in contrast with biblical struggles, which, pregnant with transcendental significance, took place in the domestic and public sphere alike. The epic reflected a static "feudal" society, and its heroes were aristocrats, the Old Testament reflected a nomadic society, its protagonists were often humble in origin, the entire social ladder was immersed in everyday life. "In the Old Testament stories, the sublime, tragic, and problematic take shape precisely in the ... everyday" [133]. The Hebrew Bible was the fountainhead of Western realism. 
The fragmentary character of biblical narrative reflected the difficulty of complete representation of any historical situation. Classical Greece discovered historical complexity and psychological intricacy and, with them, the mimetic problem-Homer's horizontal connections could no longer be easily, let alone fully, established. The classical response, from Aristotle to Horace, was the doctrine of styles, separating among high (epic), middle (didactic; historical), and low (pastoral) style. Everyday life, appropriate as popular comic subject, was proscribed from noble tragedy. Judeo-Christian writings, argued Auerbach, presaged modern realism by overcoming the separation. In the Gospel of Mark, Peter's denial of Jesus showed a lowly human undergoing psychological and emotional turmoil, "trembling for his miserable life," and acquiring through the "despair and remorse following his desperate failure" consciousness of sin, revealing to him, and us, "the significance of Christ's coming and Passion" [134]. That a fisherman would emerge as a tragic hero through an all too human failure, and that this failure would embody sublime universal meaning, was unthinkable to classical literature.

A scene like Peter's denial fits into no antique genre. It is too serious for comedy, too contemporary and everyday for tragedy, politically too insignificant for history. ... It portrays something which neither the poets nor the historians of antiquity ever set out to portray: the birth of a spiritual movement in the depths of the common people, from within the everyday occurrences of contemporary life, which thus assumes an importance it could never have assumed in antique literature [135].

Christ's dual character as Son of God and of a carpenter, his "humiliation and elevation" on the cross, broke through class barriers and literary styles, joining the humble and the sublime. The Passion forced confrontation with reality, made aristocratic distance and disdain impossible, and reshaped Western emotional life. It created a new universal message.

[M]issionary work to the Gentiles characteristically began with a member of the Jewish diaspora, the Apostle Paul [who] adapted the message to ... a far wider audience, detach[ing it] from special preconceptions of the Jewish world ... by a method rooted in Jewish tradition but now applied with incomparable greater boldness, the method of revisional interpretation [136].

Interpreting the Old Testament figuratively, the new method, typology, detached meaning from sensory perception, and deepened the antagonism between sensory appearance and meaning, emergent in the Hebrew Bible and permeating Christian reality. The great challenge, and attraction, of Christian realism consisted in this tension-in finding the transcendental represented in the mundane, in projecting an earthly world infused with transcendental meaning. Jewish Christians introduced typology as they launched universalism. Restoring early Christianity to its Jewish context, Auerbach made (pre-rabbinic) Jews shapers of Western destiny [137].

Christians still lacked a literary language. Throughout late antiquity, the Church Fathers progressively took over classical rhetoric, even as they remained suspicious and ambivalent toward it. By Augustine's time, they could speak eloquently to the educated. Yet, witnessing the waning of classical culture, Augustine, a master of rhetoric himself, recognized the need to shape a Christian style. More than anyone before, he sensed that the Passion "engendered a new elevated style," "a new kind of sublimity," "which was ready to absorb ... the ugly, the undignified, and the physically based." The result was "a new sermo humilis, a low style [that] encroaches on the sublime and the eternal," of which Augustine gave splendid examples in his writings [138]. But sermo humilis still had no capacity 
to represent concrete historical events. Typology had annihilated classical history, and Augustine's concern was to bring the Roman Empire's trajectory, not everyday life, in conformity with Christian universal history. For Christian realism to emerge, concluded Auerbach in a historicist fashion, time and "the sensuality of new peoples" were necessary [139].

Auerbach found the apex of Christian realism in the high Middle Ages - in twelfth century liturgical dramas about the Fall, thirteenth century popular religious poetry about Mary at the cross, the letters of St. Bernard and St. Francis and, of course, in Dante. They managed to bring the Incarnation and the Passion, the convergence of humility and sublimity, to bear on the common people's daily life in ways never accomplished before. St. Francis drew the imitatio Christi out of rhetoric and into his own life and became an inimitable model. Auerbach credited him - "a great poet, an instinctive master of the art of acting out his own being"-with "awakening the dramatic powers ... of the Italian language" [140,141]. St. Francis prepared the way to Christian realism's greatest work, The Divine Comedy. Mastering the typological art of transcendental significance in earthly events, Dante fulfilled the potential Augustine created with sermo humilis, and, in the very act, began its destruction. The height of Christian realism was also the beginning of secularization.

Mimesis' Christ - the Christ of sermo humilis - was the one nailed to the cross, not the triumphantly rising Christ, certainly not the judge at the end of days. He was Christ who walked among and cared for the downtrodden, was himself an outcast, and bespoke the equality and dignity of humankind. He was the Christ of Auerbach's exile and the Holocaust. A poor humiliated outcast in Istanbul, Auerbach found solace in the convergence of sublimity and humility, in sermo humilis, aptly translated as "subaltern" style [142,143]. That Auerbach saw his own condition in literary depictions of Christ is likely, that he saw the fate of his persecuted and murdered brethren in Europe in the cross is possible. Christ was Jesus of Nazareth, a Galilean Jew, son of a Jewish carpenter, but, equally crucial, he was also the Christian God.

It would be no use pretending that the ways of Christianity and Judaism never parted, and Auerbach was pursuing a Jewish agenda. In response to the Holocaust, traditional Jews turned to the Akeda and Jewish martyrology and, in anger, evoked the memory of the ancient perpetrator of genocide, Amalek [144]. Auerbach turned to Jesus on the cross, Mary at the cross, Augustine's sermo humilis, and, in the postwar years, also to Christian martyrology. Christian realism may have had its origin in the Hebrew Bible, but the world in which Auerbach found it fulfilled, that of St. Bernard, St. Francis and Dante, was as closed to Jews as any have been. That the cosmopolitan European public Mimesis envisioned would be more open to Jews was a desperate Auerbach wager (for once, a successful one). Auerbach's "stylistic analysis [was] so Christ-centred that it seem[ed] on the verge of ... a Christological literary history" [145]. The Judeo-Christian project for Jewish integration was tenuous at best.

\section{A German Jewish Cosmopolitan in Despair: Globalization, Postwar Germany and the U.S.}

"May my study reach its readers - both my friends of past years who have survived and all others for whom it is intended," concluded Auerbach Mimesis, "and may it contribute to bringing together again those who clearly kept their love for our Western history" [146,147]. His call for a survivors' meeting to learn what may be salvaged of Europe was sad and uncertain, but not hopeless: The 
cosmopolitan literary public Mimesis envisioned might yet be constituted. He still had no sense of the magnitude of the destruction. His feelings about his own future were similar: uncertain but not hopeless. He did not wish to remain in Turkey, where the enthusiasm for humanist educational reform was waning, was considering a return to Germany and, having sent his son Clemens to Harvard for graduate education in the fall of 1945, he was contemplating a move to the U.S. Mimesis' success, his 1947 immigration to the U.S., his 1950 appointment at Yale, and his growing reputation on both sides of the Atlantic represented great personal accomplishment. But his postwar reflections on the European future became increasingly gloomy. In the bipolar Cold War world, the progressive German mandarin thought his Europe was gone. The Jews were gone, the emancipation project to which he had still clung in 1941, proved a phantasm, that "side issue," as he had called antisemitism, rendering it irrelevant. He would no longer entertain any projects for a Judeo-Christian civilization. His studies now focused on early medieval Europe, trying to decipher how late antique culture survived through the dark ages, once the Western Roman Empire had been gone. His cosmopolitanism was not a happy one.

Auerbach still felt German and European. In the immediate postwar years, he was trying to reestablish connections with friends left behind and to explore the possibility of a Marburg reappointment. Just as he feared, more than a few of his friends did not survive. Students of draft age sent to the Russian front usually did not come back [148]. For the survivors-German colleagues undergoing postwar hardship_-Auerbach cared deeply. He sold furniture and books to send Clemens to Harvard, but he still went out of his way to mail Care packages to Germany, especially to his former (non-Jewish) assistant, Werner Krauss, who was in poor health after prolonged incarceration $[149,150]$. Emotionally and intellectually, he remained vested in Germany and, in many ways, would remain so all his life. Untenable as his situation in Turkey was, he still felt he needed to explain to German colleagues why a German European would send his son to study in the U.S. and explore emigrating there [151-153]. Until 1947, his preference was a return to Marburg. Had the call from Marburg arrived, Auerbach would have probably accepted it.

War and exile did transform, however, the German European Auerbach. They impressed upon him that he was not, and could never hope to be a German insider. Krauss, now a communist professor in Marburg, and later in Leipzig, did everything he could to attract him back, repeatedly broaching a Berlin appointment with the Soviet Zone's education administration. In the summer of 1946, he assured Auerbach that nothing more than good will toward socialism would be required of him. Longing for Berlin but apprehensive about its geopolitics and the ideological burden, Auerbach hesitated. "I am very liberal ... Here [in exile] I could free myself like nowhere else of any commitment; precisely my position as someone who is nowhere an insider, fundamentally and inassimilablly a foreigner, is what one wishes and expects of me; where you want me back, one expects 'basic favourable disposition'" [154]. His alienation, his sense of himself as a permanent outsider, incapable of commitment, was new. He would not have spoken of himself as a foreigner in Germany prior to the war, and even Mimesis underlined social commitment. His newly discovered marginality reinforced his move away from the nation and towards an ephemeral European cosmopolis.

Family and scholarship joined alienation to challenge the nation's call to return. His son was in the U.S., and a flood of reports about the hardship of life in Germany reached Turkey. In Istanbul, he was getting poorer, unable to afford support for Clemens at Harvard, feeling ever more dejected about the 
bureaucracy and with no career prospect. Germany had to address some of these needs, for him to return. Krauss urged upon him the importance of his repatriation for building up a new Germany: "Reintegration in the Heimat [is] an inner need that one cannot resist with impunity. ... Germany is only bearable and worth affirming as a project, not in its present state" [155]. In vain: Early in 1947, Auerbach got three offers from German universities - Greifswald, Halle and Münster, the first two in the Soviet Zone, Münster in ruins. It was evident that working conditions would be inadequate, and he declined. He admired Krauss' dedication, but, Krauss' communism aside, he could not share his commitment to Germany.

Auerbach was still waiting for Marburg - the hub of university life in the U.S. Zone, with a glorious tradition and old colleagues on the faculty, site of his fondest memories of Germany. One wonders whether he did not also think of a Marburg invitation as restitution, an apology to rectify the injustice done to him. In April 1947, he received from Marburg's reform-oriented Philosophy Dean, former Vienna Circle associate Kurt Reidemeister, a letter suggesting that if Krauss left for Leipzig, and the ministry approved a full professorship, a position would open up for him. Auerbach gave rare expression to his frustration, saying he was tired of building his career as a house of cards that repeatedly collapsed [156]. He now opted for the U.S., but he assured Krauss, only as a breathing spell: "I want to be back in Germany." Krauss called on him again, from Leipzig, in the summer of 1949, offering him to try Humboldt University in Berlin for a year. "We must have you among us," he pleaded [157]. Auerbach, his reputation in the U.S. growing, accepted shortly after a position in Yale's French Department. The two would never see each other again.

Disappointed, perhaps even bitter, as Auerbach was at having to bid farewell to Europe, he did not project his bitterness towards Germany. He acknowledged no Jewish dimension to the tragedy that befell Europe, and, if he now recognized his own liminality in German culture, he never thought of it as ethnic in origin - his liberalism, he suggested, was implicated, or his own character. Mimesis' "survivors" note- "my surviving friends of past years"- was not a veiled allusion to the Jews: The friends after whose fate Auerbach inquired were for the most part non-Jews. He was critical of people counseling the émigrés, "especially Jews," not to return to Germany, of "prominent and otherwise quite sensible people who try to exercise a kind of moral pressure" [158]. He assured Bultmann that he neither held the Germans collectively responsible for the tragedy nor thought it right to single them out for blame [159]. Like other Europeans, Germans fell victim to the contradictions of modernity. Like the Jews, they were survivors, too.

Both Bultmann and Krauss served on Marburg's "planning committee," and both warned Auerbach of creeping renazification [160]. Frustrated with university reform's failure, Krauss left for Leipzig [161,162]. Auerbach, in contrast, was skeptical about university reform and defensive about charges of nazification in the German academy [163]. He showed sympathy for German efforts to return to normalcy: "Bourgeois orderliness is ... a human need," he told former student, Martin Hellweg. "After three decades of such horrible experiments ... the Germans can be nothing other than terribly tired and in need of rest" [164]. The closest he came to implicating Germans in the Holocaust was in his letter to Klemperer, i.e., in internal Jewish assimilationist discourse: "It is strange for someone in my situation to find out increasingly that the Germans, except perhaps the Jews, are really the most efficient and, insofar as work is concerned, the most reliable people (Volk)," but, he added, "this in itself is quite insufficient. ..." [165]. Just as obliquely, he advised Germans to begin thinking 
globally again, but in a new fashion, with greater awareness of cultural difference and global needs [166]. What his innermost thoughts about the murder of the Jews were, we may never know. Like many of his generation, he said not a word about the Holocaust.

Auerbach's 1946 essay, "The Triumph of Evil in Pascal," provides, however, further hints about his view of culpability in the Holocaust. The Christian confronting evil political power was at the center. For Pascal (1623-1662), might was evil but it made right. Earthly laws were arbitrary but obedience to them was divinely sanctioned as punishment for corrupt human nature. Evil laws were just, and "one must obey unquestioningly ... without devotion, or rather from devotion to God" [167]. The Passion provided the model for suffering injustice, and liberation from it was only in the beyond. Resistance was only permitted as expression of God's will, and a good measure of its legitimacy was its hopelessness. Striving for victory was impermissible, as those seeking to suppress the resistance were also doing God's will.

Combining Augustinianism and raison d'êtat, Pascal's wretched earthly world was a far cry from Dante, and his hateful endorsement of murderous absolutism was a long way from realist social criticism. Yet, Auerbach found his ethical theory cogent and moving, and, ironically, a starting point for secular political criticism. Members of Auerbach's October 1949 Princeton seminar on Pascal sensed that they were hearing the quiet protest of a German Jewish émigré against totalitarianism. "Auerbach," said one, "had faced with his flesh and blood the reality of evil force; the extremity of Pascal's thought answered, for him, an extremity of experience. Pascal, too, had lived in a totalitarian state" [168]. True enough, but they were also hearing a vindication of good Germans (and Jews) who obeyed Hitler. Those, who offered hopeless resistance, were admirable but one could not incriminate even perpetrators who "obeyed unquestioningly, without regard for any possible benefit, but also without devotion." By the mid-1950s, Auerbach expressed his wish that Germans, and Europeans in general, rid themselves of the guilt complex, which obstructed their intellectual recovery [169].

Auerbach was never a decisive person, let alone a risk taker. He had to be forced to go to the U.S., without a promised job, in his mid-fifties, and start a fourth career. Departing from Istanbul in July 1947, the Auerbachs left behind "furniture and porcelain, ... the residues of our bourgeois past," material vestiges of Germany and Europe [170]. Emotionally and spiritually, however, they never left Europe. Auerbach held the typical German mandarin's prejudices against "America" and never rid himself of them. Western literature remained for him European literature, abendländische in the interwar sense, not westliche in the postwar trans-Atlantic sense. Mimesis made no mention of American authors. When Auerbach contemplated a new global literary public, the making of early medieval Europe provided the model, and contemporary Europe the focus [171]. He wrote in German to the end of his life, saw his major audience and interlocutors as European, repeatedly visited Europe, and, in response to German job offers, periodically reconsidered a return to the Heimat. Marie Auerbach never spoke English fluently and harked back to the blissful Marburg years [172]. The U.S. would never become the Auerbachs' cultural home.

The Auerbachs landed on the East Coast in September, "falling into [Erich's former colleague Leo] Spitzer's arms for the third time" [173]. Auerbach approached former Istanbul colleagues and German émigrés at Harvard, Johns Hopkins, and Princeton, in a desperate search for a job [174]. The U.S. was kind to him. At the Modern Language Association convention in December, he got a job for the spring 
of 1948 at Penn State College. The urbane German mandarin went for eighteen months to a state university, predominantly an engineering and natural science school, in the heart of rural America.

Writing German colleagues, Auerbach shared his impressions of rural America: from the standpoint of human relations - delightful, intellectually - below criticism [175,176]. The U.S. must be, he said, the world's happiest and easiest country to live in. Americans were sympathetic and ready to help, their optimism, naïveté, and trust in the future "strike a European who has experienced the last thirty years" as incredible. Daily interaction was relaxed, warm, and free of hierarchy, inhibition or complexity. But he found the intellectual level at Penn State unacceptably low, and he was pleased to have around a German émigré philologist with whom he could "speak European" [177]. He was aware that intellectual life was different at elite universities, but he projected from his state university to American culture. Moving to Yale in 1950 would not change his view. He had at Yale a superior library, and colleagues and graduate students the like of whom he had not known since Marburg. He appreciated them but he was still dismayed by the informal relations between undergraduates and professors and reflected unfavorably on academic sports culture. America embodied rampant modernization, the standardization and leveling process threatening European and global culture with dreary uniformity.

Auerbach's U.S. reflections reinforced his apprehensions about proposed university reforms in Germany. He was critical of American involvement and warned his friends that the U.S. academy could provide no model for Germany. The German system was, on the whole, "incomparably better," and U.S. style democratization would lower the intellectual level. He acknowledged that, "after all that happened," German universities may require change, but it should be grounded in German conceptions [178]. Mimesis probed the limits of Bildung and humanist ideals and offered an egalitarian Christian vision as an alternative. Now that humanist education faced a serious democratic challenge, Auerbach recoiled. Contemporary critics view the anxiety he expressed about the loss of diversity (Mannigfaltigkeit) in "Philology and Weltliteratur" (1952) as an appeal for cultural pluralism, or, in contemporary parlance, multiculturalism [179]. They are not wrong, but Auerbach's pluralism was a product of German mandarin discourse and reflected ambivalence about modernity and democracy, cultural pessimism (Kulturpessimismus), and anti-Americanism [180].

Auerbach remained a captive of the Bildung discourse he criticized, and this raises questions about his progressivism and cosmopolitanism. His intellectual profile defies a sharp outline. As a young man in Weimar - a George admirer and a German patriot - he was fairly conservative, but he also kept the company of Marxists, like Benjamin and Bloch. He deployed historicist categories as national spirit but they were attenuated by contextual analysis - historical, even sociological. His disposition towards the nation was ambivalent: He liked it in its premodern phase, thought well enough of nineteenthcentury democratic nationalism, but regarded ethnic and populist nationalism as destructive of the nation. He trusted German state officials and adhered to bureaucratic procedure ad absurdum (submitting, in early 1941 from Istanbul, a request to extend his permission to reside abroad), but his ideal state was always part of a cosmopolitan Europe of nations.

The colleagues Auerbach kept were, for the most part, the more liberal mandarins, like Bultmann and Vossler. Among the humanists, his response to Nazism was distinct for affirming a democratic vision of Christianity. He welcomed "the inner history of the last thousand years [as] the history of mankind achieving self-expression" but he also thought it ended in stultifying uniformity and leveling. 
A product of Protestant academic culture, his affinities were with Catholic cosmopolitanism. The epitome of upper-bourgeois Jewish urbanity, he was an advocate of Christian sermo humilis, critical of Castiglione and Montaigne for cultivating a courtly style. His class prejudice came out most in contempt for American culture and fellow Jews (and, in both cases, prejudice reflected also his resentment of their accomplishments). "Son of a Viennese Jew and an opera singer," he said of Spitzer, a colleague to whom he owed his life, "he is full of activity and tactlessness, and has very lively ideas but not even a shadow of culture and true critical spirit" [181,182]. So much for Christian clemency for Jews lacking proper composure, and yet clemency and humility remained Auerbach's cherished ideals.

Auerbach's students suggest how unconventional a mandarin he was. He was surrounded by dissenters (partly, no doubt, because he was Jewish). Hollweg and Krauss were Marxist socialists and were let off by the Nazis. Other students could not make a career in Nazi or postwar Germany. Krauss joined the Rote Kapelle (Red Orchestra) resistance group in Berlin, was arrested in November 1942, sentenced to death in January 1943, and saved only through the intervention of the Marburg faculty, which had his sentence commuted to a prison term by declaring him psychologically deranged. In the postwar years, both Helwegg and Krauss were involved in programs for the democratic re-education of Germans. Krauss helped lay the foundations of East Germany's academic culture by developing Marxist literary studies and drafting Bloch and Klemperer. Auerbach helped Krauss get the Bloch appointment through but refused to join, repeatedly making his liberal stance explicit [183]. He admired Krauss for acting on his convictions but also feared what awaited him in the Soviet Zone.

Auerbach's anticommunism never translated into Cold War politics. He was equally apprehensive about capitalist and communist modernization and resentful of what he regarded as a bipolar world squashing European diversity. More conservative intellectuals were content to use U.S. military power against communism while inveighing against the Americanization of European culture but Auerbach declined political engagement in the postwar years just as he had done in interwar Germany. If he did not advocate resistance to Nazism, he would not second anti-Soviet mobilization. Against totalitarianism, he consistently turned to Christian martyrology, first to Christ himself, then, in the postwar years, to St. Perpetua, whose triumphal vision was to Auerbach a source of consolation and unbound admiration [184]. Auerbach was by no means a conventional cultural critic but it was to disabuse intellectuals like him of their antiamerican prejudices and coax them towards a warmer acceptance of modernity and an unwavering commitment to Western liberal democracy, that the Cold War liberals established The Congress for Cultural Freedom [185]. Postwar trans-Atlantic liberalism represented hopeful cosmopolitanism, not Auerbach's pessimistic Christian humanism.

"European civilization is approaching the term of its existence," wrote Auerbach in his last, posthumously published book. "[A]lready it is beginning to be engulfed in another, more comprehensive unity" [186]. He was unable to describe the emergent "unity" but he was not looking forward to it. Already in the 1930s, he found behind fascism and nationalism-German, Italian and Turkish - "a ruse of providence, designed to lead us along a bloody and tortuous path to an International of triviality and a culture of Esperanto" [187,188]. Technologies of modernization and nationalization undermined European pluralism. The European nation, and its state, Germany in particular, could not be saved. One had now to turn from nation to humanity, and think globally. But how was global culture possible when uniformity and leveling made humanistic education ever more problematic? Goethe's cosmopolitanism, the search for Weltliteratur, did not turn out as 
expected. Globalization served as an opening not to Weltliteratur, but to morbid uniformity and a "European crisis."

What could the humanist philologist do to address the European crisis? Unable to outline a new cosmopolitanism, Auerbach sought instead "to form a lucid and coherent picture of [European] civilization" and its legacy. He looked backward to the making of Europe to learn how the decline of the West (Abendland) may be not averted but weathered. Ironically, he was perusing the history he was living - in reverse, looking at the dissolution of imperial Rome and Europe's formation, while living Europe's' dissolution and the reformation of a universal culture. Still, the cultural transmission from late antiquity to the middle ages was to yield the essence of the European legacy.

Empire was never Auerbach's ideal: He loved the late Roman Empire about as much as Augustine had. He described imperial Roman culture as living on borrowed time. Having undermined the ancient city-states' civic cultures, the Empire was incapable of cultural innovation, and became lifeless, its aristocratic literary public progressively diminishing. Empire meant stagnation. In contrast, Auerbach loved the plurality of medieval Europe, the authenticity, however primitive, of the new peoples' cultures, and the interplay between national life and " $a$ European society," between "vulgar" culture and "a European ... Hochsprache (language of high culture)" [189]. The medieval moment metamorphosized later, it seems, in the Viconian world of nations, extending into the nineteenthcentury, in Europe prior to the triumph of ethnonationalism. These were the high points of European culture, moments long gone, which Auerbach was trying to recapture as the European essence.

The flowering of European culture, Auerbach decided, was dependent on Christian reworking of the classical heritage. As the literary public, always a narrow elite, was progressively diminishing in late antiquity, Christianity became, against its will, the custodian of classical culture. Through sermo humilis, Christianity made the sublime "accessible to all, descending to all men in loving-kindness ... at one with the entire Christian congregation" [190]. Here was a model of cultural transmission appropriate for a democratic global age-Christianity helping shape a new universal culture.

What unites [European nations] is their common root in antiquity and Christianity. For this combination contains the dialectical force which - even if Europe, like Rome before it, should now lose its power and even cease to exist as such — has prefigured the forms of a common social and cultural life on our planet [191].

Christianity tied together the divergent metamorphoses of Auerbach's cosmopolitanism, from the Weimar Dante, a German European cosmopolitan, to Mimesis' wartime pan-European modernist public, to the hopeless globalism of postwar years. But the variety of Auerbach's cosmopolitanism was also grounded in the German nation. He was unable to imagine, as Austrian intellectuals did, a vital imperial culture. Hofmannsthal, Popper, Joseph Roth, Friedrich Torberg and Werfel had each to negotiate between imperial and national identities, and their cosmopolitanism reflected negotiation's results. Auerbach's cosmopolitan public remained ephemeral, and the new global culture an intangible nightmare, because he could never see beyond the Europe of nations. Once the German nation was gone, he faced the void.

The Europe of nations first emancipated the Jews, then, at its moment of collapse, murdered them. As if acknowledging the fait accompli, Auerbach's classical-Christian literary public had, in his last book, no place for the Jews. They vanished from Europe, losing even the role they had had in Mimesis, as makers of European civilization. Their disappearance reshaped Auerbach's cosmopolitanism. The 
German cosmopolitan who had begun his way hopefully with Dante and Christian engagement in the earthly world, and went into exile with Dante, bemoaning having to eat foreign bread and imagining a cosmopolitan literary public, ended up in despair with Pascal's hatred of the world and Hugh of St. Victor's espousal of permanent exile as the ground of cosmopolitanism. "The man who finds his homeland (patria; Heimat) sweet is still a tender beginner; he to whom every soil is as his homeland is already strong; but he is perfect to whom the entire world is a foreign land (exsilium)" [192,193]. Auerbach finally brought his cosmopolitanism in conformity with Jewish exile -through Christian sources and with no hope for the future.

\section{German Jewish Cosmopolitanism Triumphant: Auerbach in Contemporary Europe}

The despair and alienation characterizing Auerbach's postwar writings contrasted remarkably with their spectacular success. In the spring of 1949, just as Auerbach found out that his heart condition would make it impossible for him to continue at Penn State (he lost his university health insurance), he received an invitation to the Institute of Advanced Studies at Princeton for 1949-1950. Princeton literary critic and Dante scholar, Francis Fergusson, who had met Auerbach in Vermont late in 1947, urged the Institute Director, Robert Oppenheimer, to invite the still unknown visitor, so as to facilitate the launching of a (soon to become famous) literary seminar. The émigrés' network, above all Princeton's art historian, Erwin Panofsky, joined in lending their support. Fergusson and most U.S. critics read no German, so Auerbach's reputation was initially based on émigré reports and personal encounters. But not for long: As different Mimesis essays began showing up in 1950 in U.S. literary journals, the enchantment was immediate. The sophisticated, beautifully crafted essays were a pleasure to read. Scholarly encounters with the quietly erudite Auerbach left the impression of a rare exemplar of old world urbanity. "All around you hear nothing but Mimesis," complained a jealous Curtius, visiting Princeton in 1949 [194].

In the spring of 1950, Auerbach received a "very good offer" from Yale. Yale would become the final station in his tumultuous life: "The good traveler arrived at his destination and rested" [195,196]. He and Marie received U.S. citizenship, a security they had not known since the Nuremberg Laws [197]. A Marburg chair offer arrived, all too late, in March 1953, to find the Auerbachs staying in the U.S., not altogether happily but with pride that they no longer depended on the Heimat that had cast them out. In 1956, Auerbach became the first Sterling Professor of Romance Languages at Yale. The fall after, he died, just short of his sixty-fifth birthday.

Already in the last years of his life, Auerbach was becoming a mythical figure in the U.S., the model of the émigré scholar, survivor of a superior culture, who was propelling the American academy to new heights. Henri Peyre, a leading French Studies scholar and the chair of Auerbach's department at Yale, testified to the emerging legend: "Jew by birth (Israélite de naissance), agnostic by formation and cast of mind, painter of Greco-Roman culture and reader of the Church Fathers and Dante, [Auerbach] seemed to us to embody the precious qualities of the European humanist of the time of Lessing, Herder and Goethe" [198]. Mimesis appealed to wide and diverse audiences. Selected essays were first published in the New Critics' literary magazines. Auerbach's German historical philology challenged the New Critics' formalism, yet his agile stylistic analysis appealed to them. Reviews of Mimesis were admiring: "hailed as 'the most important and brilliant ... literary history that had been 
published in the last fifty years'," wrote René Wellek [199-201]. Wellek himself remained critical, and Auerbach's reviews of American works on Dante were a rejoinder and created an exemplary dialogue between divergent interpretive traditions. Mimesis also contributed to the emergent comparative literature field, and was popular among medievalists. No consensus has ever emerged on its arguments but there was no denial of Auerbach's achievement [202-204].

New York intellectuals, Alfred Kazin and Delmore Schwartz, wrote the first two blurbs appearing on the cover of Mimesis' paperback edition [205-207]. This was no coincidence. The post-Marxist Jewish intelligentsia sought integration into the Western literary tradition via high modernism. Mimesis provided a blueprint. Historian David Hollinger has shown how a secular cosmopolitan worldview, emphasizing scientific universalism, served the Jewish entry into the U.S. academy in the postwar years [208]. The Congress for Cultural Freedom, representing a collaboration of European remigrés and New York intellectuals, made this worldview central to an emergent liberal trans-Atlantic culture. The secular Jews usually left it to their non-Jewish colleagues to think through the possibilities of Christian cosmopolitanism for a religiously tolerant Europe. But in Auerbach they found a Christianity-inspired Jew who provided an unmatched narrative for Jewish integration into a secularized Christian West. To be sure, Auerbach left no room for ethnic Jewish consciousness, but the majority of U.S. Jewish intellectuals sought no such in the postwar years. They taught college students with relish the grand narrative of Western civilization, from Homer and the Bible via the medieval Christian West to the scientific revolution and the Enlightenment to twentieth-century modernism. Auerbach provided the ultimate vindication for the postwar Jewish secular liberal cosmopolitan worldview.

Mimesis had appeared in German in the fall of 1946, seven years earlier than the U.S. edition. European responses came a bit slower and were more muted. Germans were more familiar with Mimesis' distinctive blend of historical philology, stylistic analysis and modernism, which had been introduced by the interwar generation of humanist philologists. Europe also had no equivalent to the U.S. progressive Jewish intelligentsia to turn Auerbach's abendländische narrative into a liberal westliche one, no comparable secular Cold War liberalism. Still, numerous positive reviews established Auerbach securely as a leading German philologist. The polemics with Curtius over the history of Stiltrennung, which elicited Auerbach's reaffirmation of Mimesis'-and his own-German identity, highlighted Auerbach's prominence [209,210]. The 1953 Marburg chair offer reflected Auerbach's new status.

By the late 1960s, however, the Western civilization narrative of the Cold War years came under siege. The U.S. Jewish intelligentsia was exploring its ethnoreligious identity, the 68ers on both sides of the Atlantic challenged the Western narrative on grounds of class, gender and race and highlighted its imperialist implications, and the German 68ers, in particular, attacked the interwar philological humanists as anticommunists and fascists. Auerbach never drew as much fire as Curtius, but the critique spilled over to him, too [211]. The liberal grand narrative had not quite emerged from under the 68ers' attack when the poststructuralists demolished whatever remained of it. Mimesis seemed to have lost its luster, and Auerbach was in danger of becoming obsolete.

Just at this moment, help came from the least expected quarter-from Edward Said and postcolonial studies. Said was not known for forgiveness toward Eurocenteric Western narratives but Auerbach was an exception. From early on in his career, when he and Maire Said translated "Philology and 
Weltliteratur" (1969) to his 1983 essay collection, The World, the Text, and the Critic to one of his last essays - an introduction to a new edition of Mimesis - Said was engaged with Auerbach [212,213]. Their parallel use of Vico as an Ansatzpunkt (starting-point) for their work may have first triggered Said's interest but his emotional attachment to Auerbach was due most to a feeling of shared liminality as cosmopolitan intellectuals in exile. Both Said and Auerbach shared secularized Christian inspiration and humanist training, and yet, living on the East-West boundary, were liminal to the traditions forming them. Said captured better than anyone Auerbach's peculiar position as "a non-Christian explaining Christianity's achievement [and] in so doing, travel[ing] from his roots still further" [214].

To be sure, as representatives of their respective "minority cultures," Auerbach and Said displayed opposite attitudes [215]. Auerbach assumed distance toward his Jewishness and sought nothing more than integration in the Western mainstream. When Martin Buber requested, in 1956, that Auerbach write an introduction to the Hebrew edition of Mimesis, Auerbach declined, mentioning that he had refused a similar Italian request and was unfamiliar with Israel [216]. He made it clear he had no special relationship to Modern Hebrew culture. In contrast, Said imaginatively espoused Palestine and the Arab world, and sought to vindicate them against the West. But Said recognized that he, too, "travelled further from his roots," and, precisely because Auerbach's Jewishness was non-threatening, exile's affinities could count the most. Said was kind to Auerbach. Where I see Auerbach lamenting, as a German mandarin, modernization and Bildung's decline, Said saw him protesting nationalist uniformity, presaging the rise of other civilizations, and rescuing sense and meaning from fragments of modernity, from exile, by reconstructing an alternative European history from the margins [217]. Auerbach became a postcolonial prophet.

The last two decades have witnessed explosion of global interest in Auerbach. The search for useable concepts of global culture and transnational European history found in the Jewish German émigré, skirting the cultural and geographic boundaries of three continents, a unique cosmopolitan potential. East-German scholars may have led the way with publication, in the late 1980s, of Auerbach's correspondence with Benjamin and Krauss [218,219]. Since then, Auerbach's centenary, the fiftieth anniversary of his death, and Mimesis' fiftieth anniversary have been celebrated with major conferences and publications. Auerbach's sparse archives and surviving correspondence have been painstakingly collected and studied in detail [220]. Literary and historical studies of every aspect of his biography, work, and global reception have continuously appeared, and the stream is growing. In Great Books courses, "Odysseus' Scar" and "Farinata and Calvacante" are read in conjunction with Homer and Dante. No German Jewish émigré, other than Arendt and Benjamin, has attracted similar attention in recent decades. Auerbach has become a European and global intellectual par-excellence.

\section{Conclusions}

It is not difficult to see Auerbach's attraction for contemporary Europeans. Mimesis constructed a cosmopolitan literary public and a pan-European space, inclusive of Jews, and, due to its Istanbul production site-"a non-European, albeit Europeanizing space"-gesturing toward the East and Muslim inclusion [221]. The cosmopolitan culture (weltliche Kultur) into which Auerbach, the exile, performing as a modernist writer versed in Europe's traditions, wished to be integrated is the world Europeans would like to see themselves creating today [222]. Mimesis seems to allude to the 
Holocaust, but recollects cherished literary moments, highlights Europe's Christian past but seems to open it up universally. Auerbach projects Europe as it could have been, if only National Socialism had not triumphed: cosmopolitan and multicultural, accepting of Jews and Muslims (on condition they became secular Christians). The German Jewish émigré wrote a cultural history Europeans love, offering an overcoming of Europe's past (Vergangenheitbewältigung), in which all wish to take part.

Auerbach made no demands as a Jew. He negotiated his way into European culture via Dante. He confronted Europe and the Holocaust with Christian martyrology - with Christ on the cross, St. Perpetua, St. Augustine, St. Bernard and Pascal—not with the Akeda, Amalek or Jacob. The dark past of Jewish-Christian relations was not part of his history. His humanism articulated a society living on Christian heritage, open to non-believers who were willing, like him, to become part of the heritage. Burckhardt had created the figure of Dante as a cosmopolitan exile, and Auerbach inhabited it. The German Jewish émigré became the great mediator of European culture, the best of Europeans, a culturally Christian Jew, and the better for it.

The traditional Jewish historian cannot but feel irate about Auerbach becoming for contemporaries the paradigmatic European Jew. His life and work show Jewish assimilation at the limits of its success. His friends and associates were mostly non-Jewish, tied by genuine solidarity, friendship and love, and a shared German European culture. Most of them opposed the Nazis, and some risked their lives resisting. They do give a measure of what Germany could have been like if the disastrous turn nationalism had taken in the 1880s had not culminated with National Socialism. But they also show the limits of the Jewish life assimilation permitted, and suggest that we resist both the cultural history Auerbach offers and histories of the European Jewish intelligentsia that make him the paradigmatic German Jewish intellectual.

To be sure, the Jewish European histories foregrounding Auerbach, and the definition of Europeanness they form, are amongst the most benevolent that Jews have been offered in over two millennia. Jewish life will continue, perhaps even thrive, in Auerbach's Europe, even if traditional Jews are relegated to the margins. But contemporary Europe, where progressive Germans ease even Gershom Scholem's way back into German culture, and where appreciation of Jewish ethnicity and acceptance of Jewish difference are not uncommon, can do better. There must be other ways of writing Jewish European history.

An alternative Jewish European history cannot return to nationalist narrative. Auerbach belongs in it: a Jewish intellectual working European, specifically Christian, materials, to express universal ideals, responding to his situation as a German acculturated Jew, and, at the same time, as a secular Christian and German intellectual. Primo Levi recounts the elevation he experienced in Auschwitz when reciting the Ulysses Canto from Dante's Inferno - "you were made men, to follow after knowledge and excellence"-while walking to a paltry lunch [223]. Lodz (Litzmannstadt) Ghetto diaries describe the elevation experienced at the Jewish Orchestra's performance of German composers - the Jews seen in photos wearing the yellow star armbands [224]. Spitzer, who rebuked Auerbach for lack of ethnic solidarity, confessed in his April 1933 letter to Löwith: "I have recently heard the Passion of St. Matthew, its meaning is very timely when describing the loneliness of the persecuted" [225]. No one can deny the authenticity of these experiences or suggest that Dante, Beethoven and Bach - and even St. Matthew and the Passion - did not become part of Jewish European culture. But they cannot stand 
alone as signifiers for the European Jew and European Jewish culture. Their Europeanness entailed a loss of traditional Jewish culture, which must remain part of European history.

Visiting his Habilitationsvater in Cologne shortly after he had been appointed in Marburg, Auerbach wrote in Spitzer's guestbook: "Our subject is ... that Rome whence Christ is Roman," echoing Purgatorio XXXII: 102: "Quella Roma onde Cristo e romano" [226,227]. The Jewish historian, aware of Christian Rome's significance in Jewish history, can barely restrain himself from responding to Auerbach with Christian Rome's own wrathful cry at the Muslim reconquest of Jerusalem from the Crusaders: "Deus venerunt gentes" (Psalm 79:1) — "O God, the nations have invaded your inheritance." Instead, and more productively, the historian may confront Auerbach and Spitzer with an alternative Jewish European history, one focusing on the Jewish struggle against Rome, and highlighting the Europeanness of traditional Jewish culture.

\section{Acknowledgments}

This is a chapter in my book, now near completion, Jacob \& Esau Between Nation and Empire: A Jewish European History. I benefitted from criticism at the Triangle Intellectual History Seminar (Duke-UNC-NCSU-Wake-Forest) and the Johns Hopkins History Seminar, as well as from comments by Adi Gordon (Cincinnati) and three anonymous Religions reviewers. My debts to Auerbach scholars, particularly Matthias Bormuth and Martin Vialon, are indicated in the notes.

\section{References and Notes}

1. Erich Auerbach. Mimesis: Dargestelte Wirklichkeit in der abendländischen Literatur. Bern: A. Franke, 1946. 2nd ed. 1959.

2. Erich Auerbach. Mimesis: The Representation of Reality in Western Literature, translated by Willard R. Trask. Princeton, NJ: Princeton University Press, 1953. References to Mimesis henceforth are jointly to the English and second German edition.

3. 23 September 1949: "Ihre Art, es historisch abzuhandeln und diese immer verbleibende künstlerische Haltung durch die Jahrhunderte zu verfolgen, hat etwas durchaus pädagogisches." Photo and reprint: Süddeutsche Zeitung (27-28 May 2006): 16, with a discussion by Martin Vialon, "Passion und Prophetie. Eine Entdeckung: Thomas Manns Dankesbrief an Erich Auerbach für das Buch 'Mimesis'.”

4. American Jews and Protestants, who wished to repel late 1930s antisemitic populism and urged U.S. anti-Nazi intervention in Europe, were the first to use "Judeo-Christian" to describe a shared Western legacy. (Mark Silk. "Notes on the Judeo-Christian Tradition in America." The American Quarterly 36:1 [1984]: 65-85.) The term became common in Europe only in the postwar years. It appears neither in the Nazi attacks on humanism's shared Jewish-Christian origins nor in interwar religious and secular affirmations of Europe's Jewish-Christian origins. Auerbach may have been among the first to use it.

5. In Mimesis, "Judaeo-Christian" (jüdisch-christlich) expands from early Jewish-Christian culture (Mimesis. pp. 72, 320 [English]; pp. 73-74, 305 [German]) to a European Western mode of representing reality (pp. 119, 201 [English]; pp. 116, 192 [German]). (Thanks to Avihu Zakai of the Hebrew University for the English references.) 
6. Martin Vialon. "The Scars of Exile: Paralipomena concerning the Relationship between History, Literature and Politics-Demonstrated in the Examples of Erich Auerbach, Traugott Fuchs and Their Circle in Istanbul." Yeditepe'de felsefe 2 (2003): 198.

7. The Heidelberg information is based on a letter from Marie Auerbach to Traugott Fuchs, 11 April 1973. Martin Vialon. Erich Auerbachs Briefe an Martin Hellweg (1939-1950): Edition und historisch-philologischer Kommentar. Tübingen: Francke, 1997, pp. 82-83, n. 7. It is not altogether clear when Jaspers and Auerbach met and, if and when Jaspers read Auerbach's work. But in 1929, Jaspers and Friedrich Gundolf (1880-1931), a leading member of the Stefan George Circle, unsuccessfully pushed to appoint Auerbach in Heidelberg.

8. "The novella is situated in the midst of time and place; it is a piece of history... It must be realistic in as much as it takes for granted empirical reality ... [Its] Ethos must be not metaphysical but grounded in the laws of social community": Erich Auerbach, Zur Technik der Frührenaissancenovelle in Italien und Frankreich. Heidelberg: C. Winter, 1921, 1.

9. Erich Auerbach. "Zur Dante-Feier." Neue Rundschau 23 (1921): 1005-6. This short article commemorated the six-hundredth anniversary of Dante's death.

10. Erich Auerbach. "Stefan Georges Danteübertragung." Cultura Italiana e Tedesca 2:1 (1924): 17-20 was a laudation for George's rendering of (parts of) The Divine Comedy.

11. Both notes 9 and 10 are reprinted in: Erich Auerbach: Geschichte und Aktualität eines europäischen Philologen, edited by Martin Treml, and Karlheinz Barck. Berlin: Kulturverlag Kadmos, 2007, 407-13.

12. "Ich bin Prüßn, jüdischer Konfession": Karlheinz Barck. "Erich Auerbach in Berlin. Spurensicherung und ein Porträt.” In Erich Auerbach, edited by Treml and Barck, 197 (photo of original bio holograph).

13. Earl Jeffrey Richards. "Erich Auerbach's Mimesis as a Meditation on the Shoah." German politics and Society 19:59 (Summer 2001): 64.

14. Clemens Auerbach. "Summer 1937." In Erich Auerbach, edited by Treml and Barck, 497. Yet, somehow, Clemens must have retained, or acquired, a dim awareness of things Jewish. He noted that his parents arrived in the U.S. "on September 23, 1947, which happened to be Erev Yom Kippur!" Martin Vialon, Erich Auerbachs Briefe, p. 95, n. 1.

15. A referee argued that as "Auerbach self-identified as a Jew from start to finish," my reading of him as a cultural Christian "goes against [his] own declarations." But Auerbach acknowledged his Jewishness as a matter of fact rather than a commitment. He occasionally qualified his Jewishness by German and Christian affinities (p. $12 \mathrm{n}$. 86 below), and cared and spoke about the latter a great deal more. To Auerbach, descent marked German Jews from non-Jews but he offered no insight as to what the community of fate might mean to him. The closest he got was the startling statement (p. 14 n. 105 below) on the "uncanny existence" of postbilical Jews in the aftermath of their rejection of Christianity. His terms were Christian and theological. He also eliminated postbilical Jews from his narratives. To "Judaize" Auerbach, scholars override extensive textual and historical resistance and invent terms of Jewish affinity unavailable to him.

16. Ernst Troeltsch. The Social Teaching of the Christian Churches, translated by Olive Wyon. Chicago: University of Chicago Press, 1976, 2 vols. 
17. Matthias Bormuth. "Menschenkunde zwischen Meistern-Auerbach und Löwith." In Erich Auerbach, edited by Treml and Barck, pp. 85-87 tracks Harnack's influence on Auerbach, especially on his view of Augustine.

18. "Über das Persönliche in der Wirkung des hl. Franz von Assisi.” In Gesammelte Aufsätze. 1927, pp. 33-42.

19. Max Weber. "Science as a Vocation." In The Vocation Lectures, edited by David S. Owen, and Tracy B. Strong, translated by Rodney Livingstone. Indianapolis, IN: Hackett, 2004, pp. 29-30.

20. Ernst Troeltsch. Der Historismus und seine Probleme [1922], edited by Friedrich Wilhelm Graf, and Matthias Schlossberger. Berlin: Walter de Gruyter, 2008, 2 vols. esp. the editor's account of Troeltsch's seminar and the Auerbach-Troeltsch relationship on I: 26-30, 46, 283-84.

21. Historismus und seine Überwindung [1924] (trans. as: Christian Thought, Its History and Application [1923]), German and English, edited by Gangolf Hübinger, and Andreas Terwey. Berlin: Walter de Gruyter, 2006.

22. "Scholarship in Times of Extremes: Letters of Erich Auerbach (1933-46), on the Fiftieth Anniversary of His Death." introd. \& trans. by Martin Elsky, Martin Vialon, and Robert Stein. Proceedings of the Modern Language Association (henceforth PMLA). Auerbach to Traugott Fuchs, 22 October 1938, 122:3 (2007): 752, 755, respectively.

23. Der Untergang des Abendlandes: Umrisse einer Morphologie der Weltgeschichte [1918-1923]. 2 vols. Munich: C. H. Beck'sche Verlagsbuchhandlung, 1927.

24. Die neue Wissenschaft über die gemeinschaftliche Natur der Völker [Principi di una scienza nuova, 3rd ed., 1744], translated by Erich Auerbach. Munich: Allgemeine Verlagsanstalt, 1924.

25. Erich Auerbach. New Science: Principles of the New Science Concerning the Common Nature of Nations, translated by David Marsh. London: Penguin, 1999. In his editor's introduction (p. 39), Auerbach acknowledged Troeltsch's inspiration.

26. "Introduction: Intentions and Method." In Literary Language and Its Public in Late Latin Antiquity and in the Middle Ages (1958), translated by Ralph Manheim. Princeton, NJ: Princeton University Press, 1993, p. 7.

27. Erich Auerbach. "Vico und Herder." Deutsche Vierteljahrsschrift für Literaturwissenschaft und Geistesgeschichte 10:4 (1932): 671-686.

28. Erich Auerbach. "Heidegger ist ein furchtbarer Kerl, aber er hat wenigstens Substanz": Auerbach to Martin Hellweg, 16 May 1947. In Martin Vialon. Erich Auerbachs Briefe. p. 84, n. 8.

29. "Was für ein grossartiger Mann! Aber ich bin doch froh, dass ich ihm nicht in die Hände gefallen bin, als ich jung war": Auerbach to Karl Löwith, 26 May 1953, quoted in Matthias Bormuth, "Menschenkunde zwischen Meistern-Auerbach und Löwith." In Erich Auerbach, edited by Treml and Barck, p. 85, n. 12.

30. Hans-Ulrich Gumbrecht. "Everyday-World and Life-World as Philosophical Concepts: A Genealogical Approach.” New Literary History 24:4 (1993), esp. 753-56.

31. Gumbrecht's “'Pathos of Earthly Progress': Erich Auerbach's Everydays." In Literary History and the Challenge of Philology: The Legacy of Erich Auerbach, edited by Seth Lerer. Stanford, CA: Stanford University Press, 1996, pp. 13-35, is also helpful in understanding Auerbach in the 1920s. 
32. Auerbach may have well found the alltäglich (everyday) in German translations and literary criticism of Horace's doctrine of styles in Ars Poetica, which designated everyday language as appropriate for comedy or satire but not for tragedy. A German translation for high schools (Program des Karl-Gymnasium in Stuttgart zum Schlusse des Schuljahrs 1887-88) http://books.google.com/books?id=zSzgAAAAMAAJ\&pg=PA11\&lpg=PA11\&dq=alltagliche+a rs+poetica+horace \&source=bl\&ots=ePQABrIRLF\&sig=Pwp3xYRh7W9fPNEgBrmDR3OLf0c \&hl=en\&ei=gee6TLPLDYKglAf_vKGZAg\&sa=X\&oi=book_result\&ct=result\&resnum=6\&ved $=0 C C c Q 6 A E w B Q \# v=$ onepage $\& q \& \mathrm{f}=$ false (accessed on 17 October 2010) translates line 90 of Ars Poetica, "indignatur item privates ac prope socco," as "ebensowenig als je die gemeinalltägliche Sprache," and line 235, "non ego inornata et dominantia nomina solum," as "immer nur schmockloss schlichte, alltägliche Worte zu wählen." But the "everyday" became significant for Auerbach because of Alltäglichkeit's resonance in Weimar discourse.

33. "Racine und die Leidenschaften." 1926.

34. And "Marcel Proust: Der Roman von der verlorenen Zeit." 1927. In Gesammelte Aufsätze zur romanischen Philologie, edited by Fritz Schalk. Bern: Francke, 1967, pp. 196-203, 296-300, respectively.

35. 29 January 1933, PMLA 122:3 (2007): 745.

36. Dante als Poet der irdischen Welt. Berlin: Walter de Gruyter, 1929; trans. Ralph Manheim. New York: New York Review of Books, 2007. Auerbach advisedly used the term irdisch, meaning earthly, or worldly, and not secular. Ironically, Dante's earthliness was the fountain of secularization, but neither Dante's nor, arguably, Auerbach's worldliness was secular. The English title, rendering irdisch as "secular," could be misleading.

37. Edward Said noted it: "[T]he crucial word irdischen, or 'earthly,' was only partially rendered by the considerably less concrete "secular": "Erich Auerbach, Critic of the Earthly World." Boundary 2, 31:2 (2004): 13.

38. The term "realism" is scarcely used in Dante. In the introduction, Auerbach notes the term's vagueness, and moves on to speak of the mimetic problem. But rudiments of "everyday tragic realism" are already in Dante.

39. Auerbach, Dante (English edition), p. 8.

40. Ibid, p. 90.

41. Ibid, pp. 13-14.

42. Erich Auerbach. "Der Schriftsteller Montaigne.” In Gesammelte Aufsätze zur romanischen Philologie. 1932, pp. 184-195

43. Matthias Bormuth. "Menschenkunde zwischen Meistern-Auerbach und Löwith." In Erich Auerbach, pp. 99-101.

44. Deutscher Geist in Gefahr. Stuttgart: Deutsche verlags-anstalt, 1932.

45. Curtius to André Gide 12 July 1921: "einer kosmopolitischen (nicht internationalistischen) europäischen Gesinnung auf dem Fundament eines unbefangenen und unverzerrten nationalen (nicht nationalistischen) Gefühls." Quoted in Guido Müller. Europäische Gesellschaftsbeziehungen nach dem Ersten Weltkrie: Das Deutsch-Französische Studienkomitee und der Europäische Kulturbund. Munich: R. Oldenbourg, 2005, p. 68, n. 121. 
46. "Die geistige Bewegung in Deutschland und der französische Geist." Westdeutsche Wochenschrift. 31 October 1919, as quoted in Guido Müller. Europäische Gesellschaftsbeziehungen. 102.

47. Ernst Robert Curtius. Deutscher Geist in Gefahr. 85. Curtius spoke of secular Jews as abgefallene Juden, literally, "apostates," or better, "heterodox Jews."

48. For Curtius in Weimar, see: Hans Manfred Bock, Kulturelle Wegbereiter politischer Konfliktlösung. Tübingen: Gunter Narr Verlag, 2005, p. 61ff.

49. Erich Auerbach. "Die Entdeckung Dantes in der Romantik." In Gesammelte Aufsätze zur romanischen Philologie. 1930, pp. 176-183.

50. "Romantik und Realismus." In: Erich Auerbach, edited by Treml and Barck. 1930, pp. 426-438.

51. Das französische Publikum des 17. Jahrhunderts, Münchener romanistische Arbeiten, III. München: Hueber, 1933; "La Cour et la Ville" (1951). In Scenes from the Drama of European Literature, translated by Ralph Manheim, Minneapolis: University of Minnesota, 1984, pp. 133-179.

52. Bernard Groethuysen. Origines de l'esprit bourgeois en France: 1, L' Eglise et la bourgeoisie (1927). Paris: Gallimard, 1977.

53. Norbert Elias. Die höfische Gesellschaft: Untersuchungen zur Soziologie des Königtums und der höfischen Aristokratie (1933). Neuwied: Luchterhand, 1969. Groethuysen and Elias' fame arrived even later than Auerbach's.

54. “Über die ernste Nachahmung des Alltäglichen" (1937). In Erich Auerbach, edited by Treml and Barck. pp. 437-465.

55. Auerbach to Benjamin. 3 January 1937. In Karlheinz Barck, and Anthony Reynolds. "Walter Benjamin and Erich Auerbach: Fragments of a Correspondence." Diacritic 22:3/4 (1992): 81-83.

56. "Etwas von dem, was dieser Junge will, ist richtig. Man muss ihm den Wind aus den Segeln nehmen, indem man es besser und anderes macht": 19 May 1936. In "Erich Auerbach: Briefe an Paul Binswanger und Fritz Schalk." Romanistiches Jahrbuch 59 (2009): 178. Auerbach wrote from Geneva and was already bound for Istanbul.

57. Spitzer to Karl Löwith, 21 April 1933. Karl Löwith papers, Deutsches Literaturarchiv, Marbach, as quoted in: Matthias Bormuth. "Menschenkunde zwischen Meistern-Auerbach und Löwith." p. 98.

58. Berlin: Aufbau-Verlag, 1995, 2 vols.

59. Martin Vialon. "Wie haben Sie es geschafft, in Deutschland zu überleben? Zum fünfzigsten Todestag des großen Romanisten erstmals publiziert: Erich Auerbachs Brief an Victor Klemperer vom 7. Mai 1949." Süddeutsche Zeitung (13 October 2007): 16.

60. Surgeon Rudolf Nissen headed the Bosporus medical school; sculptor Rudolf Belling taught at the Academy of Fine Arts; urban planner Ernst Reuter, mayor of postwar Berlin, taught in Ankara, where classicist Georg Rohde established a classical library, and German musicians contributed to the state opera and conservatory. See: Azade Sehan. "German Academic Exiles in Istanbul: Translation as the Bildung of the Other." In Nation, Language, and the Ethics of Translation. edited by Sandra Bermann, and Michael Wood. Princeton, NJ: Princeton University Press, 2005, pp. 274-288. 
61. Kader Konuk. "Jewish-German Philologists in Turkish Exile: Leo Spitzer and Erich Auerbach." In Exile and Otherness: New Approaches to the Experience of the Nazi Refugees, edited by Alexander Stephan. Bern: Peter Lang, 2005, pp. 31-47.

62. Emily Apter. "Global Translatio: The 'Invention' of Comparative Literature, Istanbul, 1933." Critical Inquiry 29:2 (2003): 269-270 suggests that Spitzer, Auerbach and the journal Romanoloji Semineri Dergisi (Journal of the Romance Studies Seminar) were instrumental in developing the comparative literature discipline.

63. Auerbach to Karl Vossler, 8 June 1938, 10 October 1938, 28 April 1939. In Martin Vialon. Und wirst erfahren wie das Brot der Fremde so salzig schmeckt: Erich Auerbachs Briefe an Karl Vossler, 1926-1938. Warmbronn: Keicher, 2007, pp. 22-27.

64. Auerbach to Johannes Oeschger, 27 May 1938. In Süddeutsche Zeitung (14 October 2008): 16, with a discussion by Martin Vialon. "Wie das Brot der Fremde so salzig schmeckt: Hellsichtiges über die Widersprüche der Türkei: Erich Auerbachs Istanbuler Humanismusbrief."

65. Auerbach to Walter Benjamin, 3 January 1937. In "Scholarship in Times of Extremes." PMLA 122:3 (2007): 750-51.

66. Auerbach to Karl Vossler, 10 October 1938. In Martin Vialon. Erich Auerbachs Briefe an Karl Vossler. p. 25.

67. Kader Konuk. East West Mimesis: Auerbach in Turkey. Stanford, CA: Stanford University Press, 2010, pp. 102-132.

68. Auerbach knew he was not safe: "That we would be exiled from here, if one had the power to do so, is certain; and, then again, we lack no enemies here either." "Dass 'man' uns von hier vertreiben wird, wenn man die Macht dazu hat, steht fest, und dann werden auch hier die Feinde nicht fehlen." Auerbach to Johannes Oeschger, 27 May 1938, 16.

69. Auerbach. "Epilegomena zu Mimesis." In Erich Auerbach. edited by Treml and Barck, 1954, p. 473 , n. 12.

70. Clemens Auerbach. "Summer 1937." In Erich Auerbach, edited by Treml and Barck. pp. 495-500.

71. Auerbach to Benjamin, 23 September 1935, 6 October 1935, PMLA 122:3 (2007): 747-752, 759-760; Walter Benjamin. Berlin Childhood Around 1900, translated by Howard Eiland. Cambridge, MA: Belknap Press of Harvard University Press, 2006.

72. Auerbach to Traugott Fuchs (Spitzer's assistant who became a close friend in Istanbul), 22 October 1938, PMLA 122:3 (2007): 752-55 (German and English).

73. "Und dann zog er wieder ohne Geld ein Stueck weiter in die weite Welt": "Die Ballade von armen Jakob.” In his: Los der Menschen. Frankfurt am Main: Suhrkamp, 1987, pp. 87-98.

74. Mimesis. p. 18 (English). Jacob is one of several biblical figures Auerbach uses to argue that biblical characters are intended as real and not mere symbols. Martin Vialon, "Wie das Brot der Fremde so salzig schmeckt," quotes a 2007 report of the former head of the Rome Jewish community, Giacomo Saban, who had known the Auerbachs in Istanbul as a young student. Vialon ventures that exile may have been a motif of Auerbach's talks.

75. "Figura." Archivum Romanicum 22 (1938): 436-489.

76. Erich Auerbach. "Figura." In Neue Dantestudien, rev. ed. Istanbul: I. Horoz basimevi, 1944, pp. 11-71, translated Ralph Manheim (1959), In Erich Auerbach. Scenes from the Drama of European Literature. pp. 11-76. 
77. "Sacrae scripturae sermo humilis." In Neue Dantestudien. 1941, pp. 1-10; rev. and expanded edition: "Sermo humilis." In Erich Auerbach, Literary Language and its Public. pp. 25-67.

78. “Passio' as Passion." PMLA 56 (1941): 1179-1196. Auerbach uses "figura” rather than typology, but the latter term has been universally used for the figurative thinking he outlined. He later acknowledged the identity of the two: "Epilegomena zu Mimesis." p. 474.

79. Auerbach. Literary Language and Its Public. 335. More on sermo humilis later, when discussing Mimesis and the postwar years.

80. Locus classicus: Augustine, De civitate Dei: The City of God Against the Pagans. (English and Latin), 7 vols. Cambridge, MA: Harvard University Press, 1957-1972, I:15, V:17, XIX:18.

81. Auerbach to Karl Vossler, 10 October 1938. In Martin Vialon. Erich Auerbachs Briefe an Karl Vossler. p. 25: "Si sa di sale la pane altrui; und mich ängsten die Gedanken an weitere fremde Treppen (how salty the bread of others is; and thoughts of more foreign steps make me anxious)."

82. Auerbach quoted to Vossler Paradiso XVII: 58-60: "You shall leave everything you love most ... You are to know the bitter taste of others' bread, how salty it is, and how arduous and bitter the walk is, climbing and descending another's stairs."

83. Auerbach. "Figura." 468 (I use the original 1938 German edition unless otherwise noted), p. 53 (English), Manheim's translation.

84. Auerbach. "Figura." 454 (German), p. 34 (English).

85. Das französische Publikum des 17. Jahrhunderts, pp. 45-53. Auerbach cut this section from the postwar German and English editions of "La Cour et la Ville."

86. Emergency Committee in Aid of Displaced Foreign Scholars, Box 38, Folder 55, Manuscripts and Archives Division, New York Public Library. (Henceforth, Emergency Committee, NYPL. My thanks to Matthias Bormuth for the document.) Auerbach was responding to a questionnaire, querying, whether the Academic Assistance Council might approach religious communities on his behalf.

87. The German academic authority on typology in medieval poetry was Julius Schwietering: "Typologisches in mittelalterlicher Dichtung." In Vom Werden des deutschen Geistes, edited by Paul Merker, and Wolfgang Stammler. Berlin: De Gruyter, 1925, pp. 40-55.

88. Auerbach does not cite Schwietering and, instead, engages Gilson ("Figura." 60-61, 235-36, n. 41 [English] and 474-75, n. 37 [German]). Notwithstanding the poor library in Istanbul, this is puzzling.

89. Auerbach. "Figura." 444 (German), p. 21 (English).

90. The Last Supper, said Auerbach, was "the purest picture of the concretely present, the veiled and tentative, the eternal and supratemporal elements contained in the figures": "Figura." 474 (German), p. 60 (English). Manheim's translation.

91. Auerbach. "Figura." 461-62 (German), pp. 44-45 (English).

92. Auerbach. "Figura." 466 (German), p. 51 (English).

93. Auerbach. "Figura." 468, 470-71 (German), pp. 53, 56 (English), respectively.

94. Auerbach. "Figura." 471 (German), p. 56 (English).

95. Auerbach. "Figura." 458 (German), p. 39 (English). Dante spoke of The Divine Comedy as "allegorical" but he meant "typological": "Dante's Letter to Can Grande." Translated by Nancy 
Howe. In Essays on Dante, edited by Mark Musa. Bloomington, IN: Indiana University Press, 1964, pp. 32-47.

96. James Markham. "Epistle to Can Grande: Text and Translation.” http://www.english.udel.edu/ dean/cangrand.html.

97. Auerbach. "Figura." 478 (German), p. 63 (English).

98. Auerbach. "Figura." 477-489 (German), pp. 64-76 (English).

99. Auerbach. "Figura." 489 (German), p. 76 (English).

100. Michael von Faulhaber. Germany: Advent Sermons Preached in St. Michael's, Munich, in 1933. Unknown: Burns, Oates \& Washbourne, 1td, 1934, ibid.

101. Karl Barth. Homiletics, translated by Geoffrey W. Bromiley, and Donald E. Daniels. Louisville, KY: Westminster/J. Knox Press, 1991, p. 80 (Bonn seminar lectures, 1932-33).

102. Idem. Church Dogmatics I. 2 (1938). London: T\&T Clark International, 2004, pp. 70-101.

103. Auerbach. "Figura." 468 (German), p. 53 (English).

104. 12 December 1941, Nachlass Alexander Rüstow. Bundesarchiv Koblenz, quoted in Martin Vialon. "Helle und Trost für eine 'neue Menschlichkeit'-Erich Auerbachs türkisches Exilbriefwerk." Deutsche Akademie für Sprache und Dichtung. Jahrbuch 2010. Göttingen: Wallstein Verlag, 2011, pp. 38-40. I am grateful to Vialon for a pre-published version of his essay.

105. Ibid., p. 38: "Ihr eigenes geistiges Leben, das eigentlich Jüdische im Geistigen ist längst erstarrt und wirkt gespenstisch. [...] Das Gefühl des Unheimlichen, Fluchbeladenen wurde gesteigert und konkretisiert durch die Rolle, die sie bei der Entstehung des Christentums gespielt haben. Das Christentum ging von ihnen aus, aber sie haben es verworfen, so dass die Mission sich an die Heiden wandte und der Gegensatz zwischen dem jüdischen Gesetz (das nur noch Schatten und Gespenst sei) und christlicher Gnadenerfüllung (die das Gesetz entkräftete), konstruierte."

106. Ibid., .p. 40: "Der Antisemitismus seit etwa 1820 ist nichts mehr als eine Ausnützung solcher Atavismen im Dienste ganz anderer Ziele, er ist nur noch ein Anhängsel von sozialen und nationalistischen Kämpfen. Im Rahmen der uns erwartenden Probleme wird der Antisemitismus gegenstandslos werden, davon bin ich fest überzeugt, er ist nur noch ein Randproblem, das nie gehört werden, aber verschwinden wird."

107. Ibid., p. 38: "Alles was seither Bedeutendes von ihnen ausging, ist an die Kulturen der Wirtsvölker angerankt": This would suggest that Jews did actually make postbiblical contributions to European culture but Auerbach insists that, when a contribution was made, it would no longer be defined as Jewish but as European.

108. Landauer. "'Mimesis' and Erich Auerbach's Self-Mythologizing." German Studies Review 11:1 (1988): 88. Landauer emphasizes the intersubjectivity of Auerbach's Western tradition. This evokes a comparison with Popper. It would appear that, for Auerbach, the intersubjectivity of the Western classics relied on the community of readers' shared background, on the similarity of ideals and sentiments among benefactors of the classic-Christian tradition. For Popper, the intersubjectivity of philosophy, science and democracy required only an open critical public, an exchange of arguments. All the same, the wartime appeal of both Jewish exiles, reared on a liberal Protestant view of the West, to intersubjectivity is thought provoking.

109. Auerbach. Mimesis. pp. 547-48: In Joyce, Proust and Wolfe, "there is greater confidence in syntheses gained through full exploitation of everyday occurrence than in chronologically well- 
ordered total treatment. ... [T] his technique of modern writers [compares] with that of certain modern philologists who hold that the interpretation of a few passages from Hamlet, Phèdre, or Faust can be made to yield more ... decisive information about Shakespeare, Racine, or Goethe and their times than would systematic [biographies]. The present book may be cited as an illustration."

110. The expression "European classico-Christian literary culture" belongs to J. B. Trapp, quoted in Carl Landauer, “"Mimesis' and Erich Auerbach's Self-Mythologizing.” 95, n. 24.

111. Dante, De Vulgari Eloquentia, I, vi, lines 11-12, edited by Warman Welliver. Ravenna: Longo, 1981, (Latin and English), pp. 52-3.

112. Jacob Burckhardt. Die Kultur der Renaissance in Italien, 2nd ed. Leipzig: Seemann, 1869, p. 108. Burckhardt transformed the tormented Florentine patriot into an avowed cosmopolitan. Dante wrote: "nos autem, cui mundus est patria," translated as "I, however, to whom the world is fatherland." Burckhardt rendered it: "meine Heimath ist die Welt überhaupt!"

113. Carl Landauer. “"Mimesis' and Erich Auerbach's Self-Mythologizing.” 88.

114. Helmut Kuhn. "Literaturgeschichte als Geschichtsphilosophie.” Philosophische Rundschau 11 (1963): 222-248.

115. James Porter. "Erich Auerbach and the Judaizing of Philology." Critical Inquiry 35:1 (2008): 115-147.

116. Edward Said. "Erich Auerbach, Critic of the Earthly World." Boundary 2, 31:2 (2004): 11-34.

117. Amir Mufti. "Auerbach in Istanbul: Edward Said, Secular Criticism, and the Question of Minority Culture." Critical Inquiry, 25:1 (1998): 95-125.

118. Carl Landauer. "'Mimesis' and Erich Auerbach's Self-Mythologizing." German Studies Review 11:1 (1988): 83-96.

119. Matthias Bormuth is helpful here: Mimesis und der christliche Gentleman. Erich Auerbach schreibt an Karl Löwith. Warmbronn: Verlag Ulrich Keicher, 2006. Bormuth kindly provided me with an English translation (to be published shortly) of this hard to obtain book.

120. But his sense of the irreparable modern loss of the divine was profound: A Catholic sensibility of modernity's inadequacy complemented the ironic Protestant vision.

121. Auerbac. Mimesis. p. 202 (English).

122. Auerbach. Mimesis. p. 310 (English).

123. Esp. Mimesis, p. 550, speaking obliquely of sects "crystallizing around poets, philosophers, and scholars."

124. Auerbach. "Epilegomena zu Mimesis." p. 476.

125. Georg Lukàcs. Die Theorie des Romans: ein geschichts-philosophischer Versuch über die Formen der grossen Epik [1916]. Neuwied am Rhein: Luchterhand, 1963.

126. Shai Ginsburg of Duke University has tracked in Mimesis strong traces of Lukàcs' 1930s Essays on Realism, ed. and intro. by Rodney Livingstone, trans. by David Fernbach [Cambridge, MA: MIT Press, 1981]. He insists that these essays, and not the early Theory of the Novel, shaped Auerbach's intellectual horizons in Mimesis.

127. Georg Lukàcs. Die Zerstörung der Vernunft: der Weg des Irrationalismus von Schelling zu Hitler. Berlin: Aufbau-Verlag, 1954. 
128. Earl Jeffrey Richards. "Erich Auerbach's Mimesis as a Meditation on the Shoah." 62-91, and, more subtly, James Porter. "Auerbach and the Judaizing of Philology." esp. 119.

129. Both begin with Auerbach's statement on the rise of National Socialism as a history unsuitable for legend: Auerbach, Mimesis. pp. 19-20 (English), pp. 22-23 (German).

130. Isaac was bound (ne-ekad, נעקד) to be offered as "olah," or a "burnt offering," the Hebrew term for sacrifice, rendered in Greek as "holokau(s)ton." The term Holocaust does not become common, however, until the late 1950s.

131. Shalom Spiegel. The Last Trial: On the Legends and Lore of the Command to Abraham to Offer Isaac as a Sacrifice: The Akedah, trans. (from the Hebrew) with an introduction by Judah Goldin. New York: Pantheon Books, 1967.

132. James Porter. "Auerbach and the Judaizing of Philology." 122-23, suggests that the German Christians' use of the binding of Isaac to demonstrate the Old Testament's perversity also made the Akedah Auerbach's topic of choice for his first essay.

133. Auerbach. Mimesis. p. 22 (English), p. 25 (German).

134. Auerbach. Mimesis. p. 42 (English).

135. Ibid. pp. 45, 42-43, respectively.

136. Ibid. p. 48.

137. Contemporary scholarship would prefer "the Jesus movement" to "early Christianity" and "Jewish followers of Jesus" to "Jewish Christians." Christianity was not a religion separate from Judaism prior to the second century, if then.

138. Auerbach. Mimesis. pp. 72, 154, 72 (English), respectively.

139. Auerbach. Mimesis. p. 76 (English).

140. Auerbach. Mimesis. p. 173 (English).

141. The laudation of St. Francis, reminiscent of the George Circle, was all the more remarkable for Auerbach's acknowledgement that his style was poor. But St. Francis vividly conveyed emotional reality, and this counted for Auerbach more than aesthetics. This was evident also in Auerbach's sympathetic treatment of Gregory of Tours, and in his elevating St. Perpetua into a model of sublime humility in the postwar years: "Sermo humilis." In Literary Language and its Public. pp. 60-65.

142. Auerbach. "Sermo humilis." 39.

143. "Subaltern" is also used in the German original: Romanische Forschungen 64:3/4 (1952): 316.

144. Shalom Spiegel. The Last Trial; Gershon Greenberg. "Introduction: Ultra-Orthodox Responses during and following the War." In Wrestling with God: Jewish Theological Responses During and After the Holocaust, edited by Steven T. Katz with Shlomo Biderman and Gershon Greenberg. Oxford: Oxford University Press, 2007, pp. 11-26. The Jewish homiletic tradition that Isaac was actually sacrificed and burnt to ashes, but rose from the dead, and his ashes protect the Jewish people as zekhut (merit, זכות) against transgression and persecution makes Auerbach's turn to Christ especially poignant.

145. Helmut Kuhn. "Literaturgeschichte als Geschichtsphilosophie." Philosophische Rundschau 11 (1963): 248: Auerbach's "keineswegs christlich gedachte Stilanalyse ist doch so christozentrisch entworfen, daß sie im Begriffe zu sein scheint, sich in eine christologische Literaturgeschichte zu verwandeln." 
146. Auerbach. Mimesis. p. 518 (German); Mimesis (English), p. 557: "Möge meine Untersuchung ihre Leser erreichen; sowohl meine überlebenden Freunde von einst wie auch alle anderen, für die sie bestimmt ist; und dazu beitragen, diejenigen wieder zusammenzuführen, die die Liebe zu unserer abendländischen Geschichte ohne Trübung bewahrt haben." I modified Trask's translation.

147. James Porter. "Auerbach and the Judaizing of Philology." 118-19 called my attention to the translation difficulties.

148. Auerbach to Martin Hellweg, 22 June 1946. In Marin Vialon, Erich Auerbachs Briefe an Martin Hellweg. pp. 69-76.

149. Auerbach to Werner Krauss, 30 January 1946, 22 June 1946, 27 October 1946 and Krauss to Auerbach, 26 March 1946. In Karlheinz Barck. "Eine unveröffentliche Korrespondenz: Erich Auerbach/Werner Krauss.” Beiträge zur Romanischen Philologie 26:2 (1987): 310-16, 319-320.

150. Auerbach to Martin Hellweg. 22 June 1946, 69.

151. Auerbach to Werner Krauss. 22 June 1946, 27 August 1946, 27 October 1946, 18 December 1946, 22 February 1947, 314-17, 319, 323.

152. Krauss to Auerbach. 15 March 1947, 326.

153. Auerbach to Martin Hellweg. 22 June 1946, 69; Auerbach to Klemens von Klemperer. 7 May 1949, Süddeutsche Zeitung (13 October 2007): 16.

154. Auerbach to Krauss, 27 August 1946, 317: "Ich konnte mich hier wie nirgends von sonst jeder Bindung freihalten; gerade meine Haltung als nirgends Hingehöriger, grundsätzlich und unassimilierbar Fremder ist das, was man von mir wünscht und erwartet, aber wo Sie mich inhaben wollen, erwartet man eine 'Grundbereitschaft."'

155. Krauss to Auerbach, 29 September 1946, 318: "Ich möchte mir nämlich vorstellen, daß diese kurze Reintegration in die Heimat selbst für den letzteren Fall ein inneres Bedürfnis ist, dem man nicht ganz ungestraft widersteht. Meine letzten Erfahrungen zusammenfassend, kann ich wohl sagen, daß Deutschland überhaupt, auch für uns, nur als Project erträglich und bejahenswert ist, keinesfalls aber als ein Zustand."

156. Auerbach to Krauss. 16 April 1947, In Karlheinz Barck. "Eine unveröffentliche Korrespondenz: Erich Auerbach/Werner Krauss.” Beiträge zur Romanischen Philologie 27:1 (1988): 161-63.

157. Krauss to Auerbach. 25 October 1949, 183.

158. Auerbach to Krauss. 22 June 1946, Beiträge zur Romanischen Philologie 26:2 (1987): 312: "Besonders über die Rückkehr- und Wirkungsmöglichkeiten sind Ihre Worte sehr verschieden von dem, was man sonst hört; ganz allgemein wird davon gewarnt, zumal bei Juden, ja es fehlt nicht an prominenten und sonst ganz vernünftigen Leuten, die in dieser Richtung eine Art moralischen Drucks ausueben versuchen."

159. Martin Vialon. "Erich Auerbach und Rudolf Bultmann: Probleme abendländischer Geschichtsdeutung." In Marburger Hermeneutik zwischen Tradition und Krise, edited by Matthias Bormuth, and Ulrich von Bülow. Göttingen: Wallstein Verlag, 2008, esp. pp. 178-79.

160. Bultmann to Auerbach. 18 June 1948, in: Marin Vialon. "Erich Auerbach und Rudolf Bultmann.” p. 184.

161. Krauss to Auerbach. 23 July 1947, Beiträge zur Romanischen Philologie 27:1 (1988): 166-8. 
162. For the failure of postwar German university reform, with a focus on Marburg, see: Craig K. Pepin. "The Holy Grail of Pure Wissenschaft: University Ideal and University Reform in Post World War II Germany.” Ph.D. dissertation. Duke University, 2001.

163. Auerbach to Martin Hellweg. Easter Sunday 1948, 25 December 1948, in: Martin Vialon. Erich Auerbachs Briefe. pp. 102, 116.

164. "Bürgerlichkeit ist ... ein menschliches Bedürfnis. ... Nach drei Jahrzehnten so ungeheuerlicher Experimente ... können die Deutschen nichts anders sein als schrecklich müde": 22 June 1946, p. 69.

165. 7 May 1949, Süddeutsche Zeitung (13 October 2007): 16: "Es ist komisch in meiner Lage immer mehr festzustellen, dass die Deutschen, ausser vielleicht die Juden, wirklich das tuchtigste und in der Arbeit zuverlässigste Volk sind. Aber das allein tut es nicht ..." He would never dare write a non-Jewish German or a traditional Jew this way.

166. Auerbach to Martin Hellweg, 20 June 1950: "Die Deutschen sollten ... wieder anfangen, weltpolitisch zu denken, aber auf eine andere Weise als früher-nicht rein aus deutschen Vorstellungen und in engsten deutschen Interesse."

167. "The Political Theory of Pascal." In Scenes from the Drama of European Literature. p. 129, a slightly expanded version of the translation of the German original, published in The Hudson Review 4:1 (1951): 79.

168. Robert Fitzgerald. Enlarging the Change: The Princeton Seminars in Literary Criticism, 19491951. Boston: Northeastern University Press, 1985, p. 15.

169. Henri Peyre. "Erich Auerbach (1892-1957)/Romanist." In Marburger Gelehrte, edited by Ingeborg Schnack. Marburg: N. G. Elwert Verlag, 1977, pp. 10-11: "son rêve eût été ... de contribuer à la reconstruction des universités comme Marburg, Heidelberg, Bonn, dont il attendait beaucoup, une fois l'Allemagne et le reste de l'Europe occidentale avec elle, liberés de leur complexe de culpabilité. (His dream would have been ... to contribute to the reconstruction of universities like Marburg, Heidelberg, or Bonn, of which he expected much, once Germany and the rest of Western Europe freed themselves from their guilt complex)."

170. Another emigration, another loss, and another new start — "a somewhat late start," Auerbach told Krauss self-mockingly, "but better late than never (Ein etwas später Aufbruch - aber mieux vaut tard que jamais).” Beiträge zur Romanischen Philologie. 27:1 (1988): 9 July 1947, 166.

171. Carl Landauer. "Mimesis' and Erich Auerbach's Self-Mythologizing.” 95, n. 24.

172. Stephen G. Nichols. "Philology on Auerbach's Drama of (Literary) History." In Literary History and the Challenge of Philology. edited by Seth Lerer. pp. 63-65.

173. Auerbach to Krauss. 1 October 1947, as quoted in Martin Vialon. "Die Stimme Dantes und ihre Resonanz.” In Martin Treml and Karlheinz Barck. Erich Auerbach. p. 46, n. 1.

174. In 1940, when Auerbach was concerned about the approaching expiry of his German permission to reside in Turkey, his U.S. friends searched for a U.S. position for him and collected money to support a potential first year salary: letter of the Association of Immigrant Scholars (Notgemeinschaft) to the Committee in Aid of Displaced Foreign Scholars, 30 December 1940, Emergency Committee, 38:5, NYPL.

175. Auerbach to Krauss. 3 March 1948, In Vialon. "Die Stimme Dantes.” p. 47: “menschliches sehr gut, sachliches indiskutabel." 
176. See also Auerbach's letters to Martin Hellweg, 5 October 1947, Easter Sunday 1948, pp. 94, 102-103 and Klemperer, 7 May 1949.

177. Auerbach to Karl Vossler. 5 June 1948. In Martin Vialon. Erich Auerbachs Briefe an Karl Vossler. p. 29.

178. Auerbach to Martin Hollweg. 25 December 1948, 20 June 1950, pp. 116, 136.

179. Maire and Edward Said, trans. The Centennial Review 13:1 (1969): 1-17.

180. Fritz Ringer. The Decline of the German Mandarins: The German Academic Community, 18901933. Cambridge, MA: Harvard University Press, 1969.

181. Auerbach to Paul Binswanger. 3 March 1930, Romanistisches Jahrbuch 59 (2009): 164.

182. Auerbach knew this was unfair: Letter to Karl Vossler. 10 October 1938. In Erich Auerbachs Briefe, edited by Martin Vialon. pp. 25-26: "He is my friend, he has done for me more than anyone, he is a generous man, full of life, and a major scholar. All the same, everything he says, does and writes irritates me."

183. Krauss to Auerbach. 25 November 1947, 8 January 1950, Beiträge zur Romanischen Philologie 27:1 (1988): 170, 184.

184. Auerbach. "Sermo humilis" (English), pp. 60-65.

185. Malachi Hacohen. 'From Forvm to Neues Forvm: The 'Congress for Cultural Freedom,' the 68ers and the Émigrés.” In Das Jahr 1968-Ereignis, Symbol, Chiffre, edited by Oliver Rathkolb and Friedrich Stadler. Göttingen: V \& R Unipress, Vienna University Press, 2010, pp. 239-274.

186. "Introduction: Intention and Method." In Literary Language and Its Public in Late Antiquity and in the Middle Ages. p. 6.

187. Auerbach to Benjamin. 3 January 1937, PMLA 122:3 (2007): 750-51.

188. See also his letter to Benjamin. 12 December 1936, 749, on Turkish ur-nationalism, and to Johannes Oeschger, 27 May 1938, Süddeutsche Zeitung (14 October 2008): 16 on nationalization and modernization as "barbarization" (Barbarisierung).

189. “The Western Public and Its Language.” In Literary Language and Its Public. p. 338.

190. Ibid. p. 65.

191. Ibid. p. 338.

192. Auerbach. "Philology and Weltliteratur." 17.

193. Auerbach quotes Hugh of St. Victor, Didascalicon III: 19: The Didascalicon of Hugh of St. Victor, translated by Jerome Taylor. New York: Columbia University Press, 1961, p. 101.

194. "Man kann ja gar nichts anderes mehr hören als Mimesis": Konrad Bieber to Carl Landauer, 2 February 1986, reporting on Curtius in Princeton in 1949, quoted in: "Mimesis and Erich Auerbach's Self-Mythologizing." 83.

195. Dante. The Banquet (Il Convivio), IV: xii, par. 19, translated by Katherine Hillard. London: Kegan Paul, 1889, p. 290.

196. Dante. Opere. Florence: Bemporad \& Figlio, 1921, pp. 273-74.

197. Stephen Nichols. "Philology on Auerbach's Drama of (Literary) History." 65.

198. "Erich Auerbach (1892-1957)/Romanist." 10.

199. Wellek. “Auerbach’s Special Realism.” Kenyon Review 16 (1954): 299.

200. For a list of early reviews of Mimesis, see: Herbert Lindenberger. "On the Reception of Mimesis.” In Literary History and the Challenge of Philology. pp. 212-13. 
201. For a bibliography of Auerbach's reviews, and text of his reviews of Fergusson's and Charles Singleton's works on Dante, see: Gesammelte Aufsätze. pp. 368-69, 317-19, 313-14, respectively.

202. For the U.S. reception of Mimesis, see also: Carl Landauer. "Auerbach's Performance and the American Academy." In Literary History and the challenge of Philology. pp. 179-194 and note 201.

203. William Calin. The Twentieth-Century Humanist Critics: From Spitzer to Frye. Toronto: University of Toronto Press, 2007, pp. 43-56.

204. Among Auerbach's students at Yale were future leading literary critics, Geoffrey Hartmann and Frederic Jameson. Mimesis also inspired the linguistic turn in intellectual history, as represented by Hayden White, Metahistory. Baltimore: Johns Hopkins University Press, 1973, esp. pp. 2-3, n. 4.

205. Princeton, 1968.

206. The blurbs represented selections from their laudatory essay and review in The American Scholar 34:3 (1965): 474-498 (quotation on 484).

207. And The New York Times Book Review (29 November 1953): 40, respectively.

208. David Hollinger. Science, Jews, and Secular Culture: Studies in Mid-twentieth-century American Intellectual History. Princeton, NJ: Princeton University Press, 1996.

209. Ernst Robert Curtius. "Die Lehre von den drei Stilen in Altertum und Mittelalter (zu Auerbachs Mimesis)." Romanische Forschungen 64 (1952): 57-70.

210. Erich Auerbach. "Epilegomena zu Mimesis." Romanische Forschungen 65 (1954): 1-18. Reprint: Erich Auerbach, edited by Treml and Barck, pp. 466-479.

211. Michael Nehrlich. "Romanistik und Anti-Kommunismus." Das Argument 4:3/4 (1972): 276-313.

212. The Centennial Review 13:1 (1969): 1-17; Cambridge, MA: Harvard University Press, 1983.

213. And Boundary 2, 31:2 (2004), 11-34, respectively.

214. "Erich Auerbach." Boundary 2, 31:2 (2004): 20.

215. Amir Mufti. "Auerbach in Istanbul: Edward Said, Secular Criticism, and the Question of Minority Culture." Critical Inquiry. 25:1 (1998): 95-125.

216. Buber to Auerbach. 31 December 1956; Auerbach to Buber, 12 January 1957, In Erich uerbach, edited by Treml and Barck. pp. 488-89.

217. "Erich Auerbach." Boundary 2, 31:2 (2004): 33.

218. Karlheinz Barck. "5 Briefe Erich Auerbachs an Walter Benjamin in Paris," Zeitschrift für Germanistik 6 (1988): 688-94.

219. Idem. "Eine unveröffentliche Korrespondenz: Erich Auerbach/Werner Krauss." Beiträge zur Romanischen Philologie 26:2, 27:1 (1987-88): 301-326, 161-186.

220. Auerbach's papers are in the Deutsches Literaturarchiv in Marbach. Much of his correspondence has been published - my notes pay homage to the publications — and Martin Vialon has been preparing a comprehensive scholarly edition.

221. "The book owed its existence to the very fact of Oriental, non-Occidental exile and homelessness", Edward Said, The World, the Text, and the Critic, pp. 7-8.

222. Carl Landauer. “"Mimesis' and Erich Auerbach's Self-Mythologizing.” 89. 
223. Survival in Auschwitz (New York: Touchstone, 1996), pp. 112-115, quoting Inferno XXVI: 11617: "fatti non foste a viver come bruti, ma per seguir virtute e canoscenza."

224. Alan Adelson, producer. Łódź Ghetto (videorecording), directed by Kathryn Taverna and Alan Adelson. Westport, CT: Jewish Heritage Project, 1992.

225. Leo Spitzer to Karl Löwith. 21 April 1933, as quoted in "Menschenkunde zwischen MeisternAuerbach und Löwith.” In Erich Auerbach. p. 98.

226. As quoted in Hans Ulrich Gumbrecht. "Pathos of the Earthly Progress." pp. 25, 253 n. 46.

227. Auerbach used the phrase again in "Figura." 482, n. 43 (German), p. 236, n. 47 (English) to denote the convergence of earthly and heavenly Rome in Dante.

(C) 2012 by the author; licensee MDPI, Basel, Switzerland. This article is an open access article distributed under the terms and conditions of the Creative Commons Attribution license (http://creativecommons.org/licenses/by/3.0/). 